Pecvnia, 7 (2008), pp. 149-205

\title{
De cómo los ingleses deben comerciar en la península Ibérica: The Marchants Avizo (1589)
}

\begin{abstract}
En el año siguiente a la derrota de la Armada Invencible se publicó en Londres un pequeño manual titulado The Marchants Avizo. El contenido de esta breve guía ayuda a que el lector comprenda la perspectiva global de un mercader de la Inglaterra isabelina. Su autor, John Browne, facilita a sus lectores modelos contables apropiados para el trabajo que iban a emprender. El objeto de estas cuentas era enseñar al joven a llevar un archivo metodológico de todas sus operaciones en el extranjero y facilitar al mercader la información que necesitara para incorporarla a sus propios libros de contabilidad.

Recibido: Noviembre 2008

Aceptado: Marzo 2009
\end{abstract}

\author{
J. Lanero Fernández \\ juan.lanero@unileon.es \\ Universidad de León \\ Campus de Vegazana, $\mathrm{s} / \mathrm{n}$ \\ 24071 León (España)
}

Fac. de Ciencias Económicas y Empresariales

Conferencia de Clausura pronunciada en el VI Encuentro de Trabajo sobre Historia de la Contabilidad, Universidad de Valladolid, noviembre de 2008. 
El valor de The Marchants Avizo no solo reside en los datos que facilita sobre las técnicas comerciales, sino también en el hecho de que, en su conjunto, nos presenta un relato, narrado desde dentro, de los problemas que un mercader debía afrontar a diario en sus negocios. Además de este texto, tan solo existe otra pieza isabelina de carácter económico que pueda ser comparable con The Marchants Avizo. Se trata de un manuscrito de seis páginas de extensión, desprovisto de fecha y anónimo. Si la información que contiene este manuscrito se hubiera compaginado con la de The Merchants Avizo, el lector isabelino habría dispuesto de un manual de comercio exterior mucho más completo.

Este estudio procura realizar un estudio detallado de este manual de primer orden en el que se combinan dos objetivos: enseñar a los jóvenes técnicas comerciales y deontología empresarial.

Palabras clave: modelos contables, técnicas comerciales, ética empresarial.
The value of The Marchants Avizo does not lie only on the data it provides about commercial techniques but also on the fact that, as a whole, it presents a story, told from inside, about the problems a merchant had to face daily in his business. Apart from this text, there is only another Elizabethan document of economic nature that could be compared with The Marchants Avizo. It is a dateless anonymous six page manuscript. Should its information have been combined with The Marchants Avizo, the Elizabethan reader would have had an excellent and detailed manual on overseas trade.

This paper tries to study thoroughly the outstanding manual in which two aims are targeted: Teaching young people commercial techniques and business ethics.

Key words: Accounting models; commercial techniques; business ethics.

En el año siguiente a la derrota de la Armada Invencible, se publicó en Londres un pequeño manual titulado The Marchants Avizo ${ }^{1}$. Era obra de un experimentado mercader de Bristol, John Browne, que parece haber sido el primero en advertir la conveniencia de proporcionar a los jóvenes, que iniciaban su carrera comercial, un manual de información y asesoramiento sobre los problemas que se les pudieran presentar al asumir la responsabilidad de representar los intereses de sus patronos en el extranjero.

Este breve vademécum, de unas setenta páginas, constituía una obra de referencia práctica para las monedas de Portugal, España y Francia; facilitaba a los lectores modelos de cartas en los que basarse para su correspondencia; les enseñaba a llevar una contabilidad sencilla;

The Marchants Avizo. Very Necessarie for Their Sonnes and Seruants, When They First Send Them Beyond the Seas, As To Spaine and Portingale or Other Countreyes. Made by their hartie wellwiller in Christ. I.B. Marchant. Eccles. 40.18. To labour and to be content with that a man hath, is a sweet life: but the feare of God is aboue all, \& c. Imprinted at London by Richard Field for William Norton, dwelling in Paules Churchyard at the signe of the Queenes armes. 1589. 
y les suministraba ejemplos de documentos mercantiles con los que se podían encontrar en el transcurso de una transacción comercial.

Pero el autor no sólo se ocupa de la técnica empresarial. Tenía mucho que decir de la práctica religiosa y de los principios morales que necesita un joven mercader. Aquí radica el interés considerable de The Marchants Avizo: es uno de los primeros libros con esta temática; nos presenta cómo era la formación del hombre de negocios a finales del siglo $\mathrm{XVI}$; y, en cierto modo, ayuda a que el lector comprenda la perspectiva global de un mercader de la Inglaterra isabelina.

II

En la primera página de todas las ediciones de The Marchants Avizo, la identidad del autor se oculta bajo el pseudónimo "I.B. Marchant"; y en las posteriores a 1591, no hay ningún otro indicio del nombre del escritor. Pero, de lo que se desprende de las ediciones de 1589, 1590 y 1591, desconocidas hasta fecha reciente, existirían dudas fundadas de quién escribió el libro, dado que en Bristol, a finales del siglo XVI, había, al menos, media docena de mercaderes con las iniciales J.B. ${ }^{2}$. El Teniente Coronel Bramble ${ }^{3}$, que sólo conocía la edición de 1607, indica que el autor era John Barker y, desde la exclusiva evidencia interna, es posible defender esta hipótesis, pues el nombre de John Barker ${ }^{4}$ aparece en el libro. Fue un mercader prominente que, en 1583, era tesorero de la Company of Merchants, que tenía vínculos comerciales con España y Portugal, países a los que The Marchants Avizo dedica una atención especial. Afortunadamente, la duda se despeja con la dedicatoria que aparece en las ediciones de 1589, 1590 y 1591. Dice así:

2 La letra mayúscula "I" se utilizaba habitualmente para la "J". Resulta sencillo comprender que, en The Marchants Avizo, "I.B." corresponde a "J.B.".

3 Lt. Colonel Bramble, "A Rare Bristol Book," Proceedings of the Clifton Antiquarian Club, 1888-1893, Exeter, 1893, pp. 251-258.

4 John Barker fue un mercader destacado de Bristol en el siglo XVI y principios del XVII. Antes de que se conocieran las primeras ediciones de The Marchants Avizo, se le atribuyó la autoría de esta obra. Fue Sheriff (1593-94) y alcalde (1606-7). Murió el 13 de septiembre de 1607. Ocupó el cargo de Assistant General de la Spanish Company en 1583. Se conserva la contabilidad que llevó durante ese año. John Barker fue socio de Robert Aldworth y otros para sus negocios en Portugal, en 1600. Véase Patrick McGrath, ed., Records Relating to the Society of Merchants Venturers of the City of Bristol in the Seventeenth Century, Bristol Record Society, 1952, pp. XV y $1 \mathrm{ff}$. 


\section{TO THE WOR S H I P F V L MAISTER THOMAS ALDWORTH \\ Marchant of the citie of Bristowe: and to all the worship- full companie of the Marchants of the said citie: your bounden in good will lohn Browne, wisheth vnto your worships, felicitie in heauen, and prosperitie in earth.}

Ignoramos por qué, en las ediciones posteriores a 1591, el nombre de John Browne fue sustituido, sencillamente, por sus iniciales. Es de agradecer que las primeras versiones tengan respuesta para la incógnita de la autoría y hagan innecesario indagar sobre la legitimidad de otros pretendientes con el mismo nombre.

La tarea de precisar quién fue el John Browne que escribió The Marchants Avizo nos la facilita el hecho de que, de los alcaldes de Bristol de finales del siglo XVI, pocos se llamaban así, y tan sólo dos eran mercaderes. En realidad, la elección está entre el John Browne, que fue alcalde de Bristol en 1572, y su hijo John Browne, que fue bautizado el 3 de Agosto de 1559. El primero era aprendiz en 1538. Suponiendo que no tuviera menos de doce años cuando comenzó su aprendizaje, tendría unos sesenta en 1589, año de la publicación de The Marchants Avizo; y su hijo, John Browne, unos treinta. No podemos excluir, tajantemente, la posibilidad de que el John Browne joven escribiera el libro, aunque parece improbable, pues la obra tiene visos de ser el fruto de un mercader maduro y experimentado. Además, como veremos más adelante, hay indicios que nos hacen pensar que The Marchants Avizo se había terminado de recopilar varios años antes de 1589, época en la que el Browne joven todavía se encontraba en la primera etapa de su carrera. Por último, si éste fue el autor, bien podía haberlo indicado de alguna forma, con lo que hubiera evitado la tendencia de atribuir la obra a su padre.

El autor de The Marchants Avizo provenía de una familia de Bristol, que había ocupado un lugar destacado en el comercio español desde comienzos del siglo XVI. Era, a su vez, hijo de otro John Browne, un mercader de paños de Bristol. Este John Browne ya había muerto cuando, el 10 de septiembre de 1538, su hijo inició su aprendizaje con un mercader de la misma ciudad, William Spratt. Los aprendices debían cumplir una servidumbre de doce años. Es probable que no la terminara, pues aunque los aprendices no podían casarse, sabemos que, el 14 de febrero de 1546, John Browne contrajo matrimonio con Margaret Cooke 
en la iglesia de St. Nicholas de Bristol. El primer hijo nació el 6 de febrero de 1547 y lo bautizaron con el nombre de Roger, como su abuelo materno, Roger Cooke, mercader y concejal de Bristol, que ya había fallecido. El índice de mortalidad infantil era muy alto en el siglo XVI, y de los seis hijos que tuvieron, sólo vivían John y Alice cuando su padre hizo testamento en 1595.

Poco sabemos de los primeros pasos que dio John Browne en su carrera de mercader; si bien, de su libro deducimos que todavía era aprendiz cuando viajó a España y Portugal, en representación de su patrón, y reparó en la necesidad de disponer de una guía como la que él, posteriormente, iba a recopilar.

Aunque los Burgess Books $s^{5}$ de Bristol no indican cuándo obtuvo John Browne la licencia para establecer su propio negocio, suponemos que fue a finales de 1545 ó principios de 1546. Posiblemente, su suegro, destacado mercader, le echó una mano en los primeros años de su carrera. El joven debió establecerse con rapidez y demostrar su habilidad para los negocios, porque, en septiembre de 1558, fue elegido para ser uno de los dos sheriffs de Bristol. También es probable que por esa fecha fuera miembro del Common Council de la ciudad, un grupo selecto de cuarenta personas, en cuyas manos se concentraba el control absoluto de los asuntos municipales. De su colegas en el consejo, destaca Thomas Aldworth ${ }^{6}$, mercader afamado, al que está dedicado The Marchants Avizo.

En 1572, John Browne fue elegido alcalde de Bristol. La Adam's Chronicle of Bristol ${ }^{7}$ dice:

This mayor kept the like watches on those nights [Midsummer Day and St. Peter's Night] but turned the

5 La colección soberbia de Apprenticeship Books y Burgess Books de la Bristol Record Office, y de la que hemos tomado buena parte de los datos expuestos hasta aquí, es rica en detalles relacionados con los Browne y Aldworth.

6 Thomas Aldworth fue uno de los mercaderes más importantes de Bristol, en la segunda mitad del siglo XVI. Fue miembro del Common Council de 1566 a 1594, concejal de 1591 a 1599 , sheriff de 1566 a 1567, alcalde de Bristol de 1582 a 1583, en 1589, y de 1592 a 1593 . Falleció el 25 de febrero de 1599 (Véase A.B. Beaven, Bristol Lists, Bristol, 1899). Fue uno de los tres "Assistants" de Bristol para la escritura de constitución de la Spanish Company, en 1577 (Véase V.M. Shillington and H.B. Wallis Chapman, The Commercial Relations of England and Portugal, London, n.d., p. 317). Thomas Aldworth se asoció con John Browne cuando el barco Peter de Bristol naufragó y su valioso cargamento cayó en manos de los habitantes de Somerset, Cornwall y Sur de Gales (Acts of the Privy Council, 1575-77, p. 113). Se conserva una copia de su testamento en la Bristol Record Office (Great Orphan Books, III. 64 [V] ff). Tiene dedicada una lápida monumental en St. Mark's Chapel de Bristol (Véase William Barrett, The History and Antiquities of the City of Bristol, Bristol, 1789, pp. 350-51). 
same into a general muster in warlike sort; and all the burgesses being fully armed with all sorts of warlike weapons, every craft and science several by themselves with their drums and colours, which was well used and made a comely show.

Y prosigue afirmando:

Also this mayor caused a reformation to be made for the measures of barrels and kinter kins, which were made larger and of a bigger size than before.

Podemos comprobar el interés del alcalde por lo militar en la relación formidable de armas que legó a su hijo. Las reformas que llevó a cabo en las medidas de los barriles y quintales fueron, quizá, reflejo de su interés por los pesos y medidas que demuestra tener en las páginas de The Marchants Avizo ${ }^{8}$.

Los libros de contabilidad municipales, conocidos como The Mayor's Audits ${ }^{9}$ nos permiten pasar revista a algunos hechos acaecidos durante la alcaldía de John Browne; así, sabemos que los actores de los condes de Worcester, Sussex y Essex, visitaron la ciudad y recibieron dinero por actuar ante el alcalde y los concejales. Es de lamentar que no se especifique qué obras teatrales representaron. Se abonaron seis chelines y ocho peniques a "my lord of Leycestres bereward for bayting this beares before mr mayer and thaldermen". El interés de John Browne por los servicios públicos de la ciudad se refleja en el detalle de que se plantaron diez olmos en la marisma "by the commandement of mr mayer".

La primera autoridad municipal también debía ocuparse de asuntos de más peso. La política de servicios públicos de la Inglaterra isabelina exigía que los gobernantes locales se esforzaran en inspeccionar que la provisión de víveres se pudiera obtener a un precio razonable. En 1572, el chamberlain de la ciudad y su ayudante viajaron a Londres, por orden del alcalde y de los concejales, para conseguir una carta del Lord Treasurer "for the staying of 2 trowes of corne and to have ordre to sell yt in the market". En otra ocasión, las tremendas controversias religiosas de la época tuvieron su repercusión local cuando llegó a la ciudad un emisario

\footnotetext{
8 Las Ordinances of Common Council documentan algunos detalles del mandato de John Browne al frente de la alcaldía de Bristol.

9 The Mayor's Audits recogen los pagos efectuados durante la alcaldía de John Browne y firmas suyas, en su condición de interventor de cuentas.
} 
de Londres con un bando "touching the calling in of the bokes named the admonytion to the parliament". De este edicto se ha dicho que marcó la aprobación definitiva, por parte de algunos puritanos, de una plataforma presbiteriana y, por lo tanto de una política "revolucionaria". El gobierno se mostraba preocupado y deseoso de eliminarla. Sería interesante saber si el alcalde conservó alguna copia y, en ese caso, qué hizo con el libro. El archivo sólo dice que el adelantado recibió cinco chelines.

Otra de las funciones, que correspondieron al alcalde, durante su mandato, incluye el hospedaje de Mr Toby Mathew que predicó tres sermones en St. Mary Redcliffe durante la semana de Pentecostés. A John Browne se le pagaron diez chelines por el importe de tres cenas del predicador. Con motivo de la reunión oficial de la Bristol Admiralty Court, hubo que pagar "for $i$ gallon of claret xvid, for i gallon secke ijs and for iiijlbs of sugar iiijs geven to mr mayer that day according to costume".

The Mayor's Audits contienen un buen número de firmas de John Browne, de 1561 a 1594. La frecuencia con la que se requerían sus servicios, en su condición de interventor de cuentas, indica que su pericia era muy apreciada por sus compañeros concejales. Hay que resaltar, por lo que veremos más adelante, que, para estas tareas, solía trabajar con Thomas Aldworth.

El hijo de John Browne obtuvo su licencia de mercader el 23 de agosto de 1582 . Es probable que su padre recopilara The Marchants Avizo para su instrucción y beneficio, dado que, según reza en el libro, el padre lo había "onely made private for instruction of me and mine".

Un hombre de los recursos y destrezas como los de John Browne, que estaba tan bien dotado para las responsabilidades y gastos de la alcaldía, se vio en la situación de tener que aceptar el cargo en más de una ocasión. Por razones de edad, entre otras, a mediados de la década de 1580, John Browne ya no estaba dispuesto a aceptar tan pesada carga, a la vez que pudo sentir la necesidad de dedicar más tiempo a escribir. Una explicación de esta naturaleza es la que, sin duda, subyace en una anotación de The Mayor's Audits, correspondiente al 22 de septiembre del ejercicio de 1585-86:

Received of Mr. John Browne Alderman the somme of xxli in monney which he giveth to the Mayor and Comminaltie with $x j$ peces of Ordynance, viz. vj Fawkenettes of yren with their carriages, and fyve small Rabnettes of brasse, In consideration whereof he is by the Consennt of Mr Mayor thaldermen and the whole 
common counsell for ever hereafter dicharged of thoffice of Mayraltie of this cittie. I saie received in monney xxli.

El pequeño libro de John Browne vio la luz en 1589; el autor murió seis años después de la publicación. Su testamento ${ }^{10}$ lleva la fecha de 1595 y, aunque no dice nada de The Marchants Avizo, es una de las fuentes principales para extraer datos sobre el autor. Por el testamento sabemos que John Browne se casó con Margaret Cooke, hija de Roger Cooke, a la sazón mercader y concejal de Bristol. Todavía vivía cuando se redactó el testamento, lo mismo que sus hijos John y Alice. John Browne, hijo, se casó y tuvo cuatro hijos: William, Thomas, Jeremiah y Grace. Alice, a su vez, se casó con John Roberts y vivió, según nos dice su padre, John Browne, con su marido, "in the backer part of my house".

Como muchos mercaderes de la época, John Browne tenía un buen capital invertido en propiedades en Bristol. Su legado comprendía "the fee simple of my dwelling house upon the back...", "two tenements with the sellers underneath them" en Marsh Street, una casa de inquilinos en Wine Street, y un jardín en Redcross Street. Además, dejó "my gret house upon the back where my father in law dwelt", "the next house adjoining the aforesaid great house", y una casa en propiedad absoluta en la zona denominada Weir. Tenía también ciertas propiedades arrendadas.

Otra parte de la herencia consistía en una cantidad de dinero que ascendía a 400 libras. A su esposa se le asignó una pensión anual de 18 libras, que abonaría la corporación de Bristol. El testamento relaciona, con cierto detalle, muebles, plata y otros enseres domésticos, como "my silver basen and yore of percell gilt wainge 66 ounces", "one dozen of Spoones with Apostells heddes wainge 14 ounces", y "my great Venis chest and a greate Ellen Chest which lieth att my Chamber dore".

En una época en la que se podía militarizar a la ciudadanía, para reprimir las revueltas populares o las invasiones extranjeras, no era sorprendente encontrar armas en la casa de un pacífico mercader. John Browne estaba muy bien provisto para afrontar cualquier emergencia. A su hijo le dejó el siguiente arsenal:

10 Se conserva una copia del testamento de John Browne en el Great Orphan Book (Register Book of Wills), vol. III, fo. $6 \mathrm{ff}$. 
...all my Armor, that is to say, Corslett of proofe, Target of proofe, $i j$ muskettes, $v$ Callivers, $x i j$ staves of halbertes, certen hedpeaces, a corslett for a pickman, with all other Armor and furniture therto belonginge.

Resulta arriesgado deducir el carácter de una persona por los términos en los que haya redactado su testamento. La expresión de creencias religiosas, que suelen aparecer en este tipo de documentos, puede ser fruto de las formas convencionales del momento. No obstante, el tono de este testamento confirma la impresión que nos da The Marchants Avizo: para John Browne la religión era algo muy importante. Además, observamos que era una persona amable y bondadosa. Hizo buenas previsiones para el bienestar y comodidad de su esposa, y dispuso que su hija y yerno continuasen viviendo en "the backer part of my house" hasta que concluyera alguno de sus contratos de arrendamiento y pudiesen instalarse en otro lugar. También dejó bienes con el fin de que "good strong shirts and smocks... to be given to the poore men and weoman of the Almehouse, in the Marshe and to others that are the most needfull poor of the said parish". Igualmente, destinó 13 chelines al año para ayudar a pagar la reparación de la iglesia de St. Nicholas, parroquia a la que pertenecía y en cuya cripta deseaba que lo enterrasen. Sus capataces deberían ocuparse de vestir a doce mujeres y doce hombres pobres "before my departinge from the worlde". Tres días después de firmar el testamento, John Browne añadió un codicilo en el que detallaba algunos objetos para sus amigos "for a token of my love and goodwill".

El 14 de julio de 1595, John Browne era enterrado en la cripta de St. Nicholas, cumpliéndose su deseo ${ }^{11}$. No se conserva ningún monumento conmemorativo, aunque The Marchants Avizo ha sido más perdurable que la piedra o el mármol.

III

El autor de The Marchants Avizo se ocupa, fundamentalmente, del comercio con España y Portugal. Es cierto que

11 En la Bristol Record Office se conserva el registro parroquial de la iglesia de St. Nicholas, en el que figuran los datos de la boda y de los funerales de otros miembros de su familia. 
hace una breve referencia a la moneda y a los pesos y medidas de Francia. Por el contrario, no menciona a Irlanda, a pesar de la importancia de sus relaciones comerciales con Bristol. La mayoría de los ejemplos, que recoge en el libro, se refieren a los negocios con la Península Ibérica. Es probable que, en buena medida, se inspirase en su experiencia personal. En cualquier caso, el comercio con España y Portugal tenía una referencia especial en la vida de Bristol en particular, y de todo el país en general.

El Embajador español en Londres escribía, en 1580, que el comercio con España era de suprema importancia para los ingleses, por constituir la fuente principal de sus riquezas y de su poder. Según el diplomático, no tenían ninguna otra relación comercial más rentable, debido a las grandes sumas de dinero que reportaba, imposibles de obtener en otro lugar, y a la variedad y riqueza de las mercancías que transportaban. En 1586, un representante español en Inglaterra señalaba que los ingleses estaban muy preocupados por la guerra con España, pues todo el país tenía paralizado el comercio, y no sabían cómo remediar el problema, dada la importancia del transporte marítimo y del comercio con España y Portugal ${ }^{12}$. La nota a la primera estrofa del poema en The Marchants Avizo, que alude a la "long staye of marchdntes [sic] trade, to the great decay of many a one"13, indica la importancia de este comercio para los ciudadanos de Bristol, pues la grave crisis comercial de 1586-87 se debió, en buena parte, a la disminución del nivel de negocios con España y sus dominios. Los efectos de la crisis fueron especialmente agudos en la parte occidental del país.

Durante el reinado de Isabel I (1558-1603), el comercio con España sufrió varias interrupciones, incluso antes de que estallara la guerra. Sin embargo, durante el tiempo en el que es probable que se recopilara The Marchants Avizo, la situación era razonablemente satisfactoria. Desde 1573, las relaciones entre España e Inglaterra mejoraron de forma considerable; y un tratado firmado entre Inglaterra y Portugal resolvió, durante algún tiempo, las diferencias entre los dos países. Incluso la conquista de Portugal por España, en 1580, no interrumpió el

12 Véase Patrick McGrath, ed., Records Relating to the Society of Merchant Venturers of the City of Bristol in the Seventeenth Century, Bristol Record Society, 1952.

13 En las ediciones posteriores a 1591, se añadió la fecha "1587" al final de esta nota. Esta aclaración no fue necesaria en las primeras ediciones cuando la profunda crisis comercial de 1586-87 era todavía reciente y su recuerdo permanecía vivo en la memoria del pueblo. 
comercio, pues, aunque Isabel I llegó a considerar dar su apoyo al pretendiente portugués, Don Antonio, no tuvo repercusiones serias en las relaciones comerciales. En 1584, Felipe II accedió a la designación de un ciudadano inglés como cónsul en Lisboa y confirmó los privilegios de los mercaderes ingleses en esta ciudad. Los negocios con España y Portugal eran de tal importancia para los ingleses, que incluso después de 1585 se hicieron esfuerzos para continuar con ellos de forma clandestina.

En 1577, Isabel I, continuando con la política Tudor de apoyar "a well-ordered trade"14, emitió una patente de invención, concediendo el monopolio de los mercados español y portugués a los miembros de la recién creada Spanish Company. Los socios fundadores eran cortesanos y funcionarios, más de 200 de Londres y 173 mercaderes de otros puertos del país. La importancia comercial de Bristol se refleja en el hecho de que setenta y seis de estos miembros de provincias, eran bristolianos, y que la ciudad aportó tres de los cuarenta Assistants, de los que uno fue Thomas Aldworth. Los socios de Bristol debían atenerse a la normativa general de la compañía, que tenía su sede central en Londres, pero todo parece indicar que habían constituido una sucursal local con funcionarios y contabilidad propios. Se desconoce qué relación mantenía esta filial con la Society of Merchant Venturers de Bristol, que había recibido su escritura de constitución en 1552; pero hay algo cierto: ningún bristoliano podía tener relaciones comerciales con España y Portugal si no pertenecía a la Spanish Company. El expediente de aprendizaje de Robert Aldworth, que se conserva en la Bristol Record Office, dice explícitamente que su patrón era "one of the Society of merchants trading to Spain and Portugal"15; hay anotaciones similares incluso durante el período en el que Inglaterra estuvo en guerra abierta con España.

La naturaleza del comercio entre Inglaterra y la Península Ibérica está descrita, extensa y detalladamente, en un documento manuscrito titulado $A$ speciall direction for divers trades of merchaundize to be used for soundrie places upon adverticementes, aswell for the chusinge of the time and wares for every of those placis. Most Beneficiall

14 Para una buena exposición de las técnicas del mercado anglo-español, véase Gordon Connell-Smith, Forerunners of Drake: A Study of English Trade with Spain in the Early Tudor Period, Longmans, Green and Co., London, 1951.

15 Robert Aldworth era sobrino de Thomas Aldworth. 
for those that use the trade of marchandize ${ }^{16}$, que es muy probable que lo escribiera un mercader de la parte occidental del país, entre 1575-85. Las mercancías que se enviaban desde Inglaterra a España tenían varios destinos e incluían:

\begin{tabular}{|c|c|}
\hline $\begin{array}{l}\text { All the } \\
\text { yeare with } \\
\text { wheate }\end{array}$ & $\begin{array}{l}\text { item, for all the partes of Galicia, course cloth and } \\
\text { Bridgwaters, northeren halfe clothes, manchester cottons, } \\
\text { hides, cal[f]skines, shepskines, dressed brecknockes, } \\
\text { bristowe frises, and tymbie fryses, wexe, flaninge and } \\
\text { wedmodes of Wales, wheate, Butter, chease, highe }\end{array}$ \\
\hline
\end{tabular}

A cambio, compraban vino, naranjas, limones y madera. Andalucía recibía pieles, cueros de becerro, carsayas, plomo, estaño, duelas para cubas, cobre, bronce de campanas y otras mercancías; y enviaba sal, aceites, resinas, sedas, cochinilla, añil, cordobán, zumaque y jabón ${ }^{18}$. Los ingleses exportaban a Lisboa mantequilla, queso y ricas telas de Bristol y Somerset. A cambio recibían aceite, sal, jabón, calicó, especias y otros productos de las Indias Orientales. La ciudad gallega de Bayona y portuguesa de Oporto recibían mercancías similares a las que se mandaban a Lisboa, exportando, a su vez, naranjas, limones y cebollas. Bilbao y San Sebastián importaban pieles, cueros de becerro y paños Somerset de Shepton Malket, Bridgwater y Taunton; y enviaban hierro, aceite, pez, azúcar, orozuz (regaliz), hojas de espada y otras mercancías.

El comercio con la Península Ibérica era, por lo tanto, muy importante para los mercaderes ingleses, en el que Bristol desempeñaba un papel destacado. La situación geográfica de la ciudad le permitía ser un centro distribuidor y de recogida de productos de una zona amplia del

16 La primera impresión de $A$ Special Direction... la realizó Conyers Read en The English Historical Review, XXIX (1914), pp. 515-524. Posteriormente la publicaron Norman Scott Brien Gras en The Evolution of the English Corn Market: From the Twelfth to the Eighteenth Century, Harvard University Press, Cambridge, Mass., 1915, pp. 429-439; y R.H. Tawney and Eileen Power en Tudor Economic Documents, Being Select Documents Illustrating the Economic and Social History of Tudor England, 3 vols., Longmans, Green and Co., London, 1924, vol. III, pp. 199-210.

17 Conyers Read, opus cit., p. 516. La itálica es nuestra, pues conviene precisar el significado de algunas palabras. Bridgwaters: gama de paños de lana, denominados según el lugar donde se hacían. Manchester cottons: un tejido similar a la frisa (tela de lana). Flaninge: franela. Wedmode (también llamado wadmal): variedad basta de paño de lana.

18 Los Profesores Salvador Carmona y Rafael Donoso han investigado a fondo la industria jabonera andaluza en su trabajo "Cost Accounting and Dialogue: The Case of the Royal Soap Factory of Seville (1525 and 1615)", presentado en The 17th Annual Congress of European Accounting Association, Venecia, 1994 
interior del país. Bristol era también un puerto de paso del comercio de Gales e Irlanda. Para los mercaderes de Bristol de finales del siglo XVI, los mercados español y portugués eran de interés, debido a la política de restricciones impuesta a los negocios con otros países. Es verdad que los bristolianos también trataban con Irlanda y Francia, pero estaban expresamente excluidos, por las escrituras de constitución de los Bristol Merchant Venturers, del importante mercado de paños inglés en Holanda y norte de Alemania. A partir de 1581, el comercio levantino se fue quedando, poco a poco, bajo el control de los londinenses.

The Marchants Avizo fue concebido, en buena medida, para instruir a los jóvenes en su primer viaje a dos países que eran, o habían sido hasta el estallido de la guerra, el principal mercado para los mercaderes de Bristol.

Aunque William Norton ${ }^{19}$ registró The Marchants Avizo el día 3 de octubre de $1589^{20}$ :

1-16 October] Anno Domini 1589. Annoque Regni Regin[a]e Elizabeth[æ]

XXXJmo/

Die veneris Tercio Die Octobris

19 Para documentar los datos biográficos de William Norton véase el Dictionary of National Biography. Por lo que se refiere a su labor profesional, la obra de E. Gordon Duff, A Century of the English Book Trade: Short Notices of All Printers, Stationers, Book-Binders, and Others Connected with It from the Issue of the First Dated Book in 1457 to the Incorporation of the Company of Stationers in 1557, London: Printed for the Bibliographical Society, by Blades, East \& Blades, 1905. En el registro correspondiente a William Norton, dice lo siguiente: "NORTON (William), stationer in London, was born in 1527. He was an original member of the Stationers' Company on its incorporation in 1557 and rapidly rose to a high position. He was collector in 1563 and 1564, UnderWarden in 1569-70, Upper-Warden in 1573 and 1577 and Master in 1580, 1586 and 1593. He did not print himself but had a very large number of books printed for him by others. His address was the king's, afterwards Queen's, Arms in St. Paul's Churchyard and he used as a device a tun having the letters Nor upon it and a spring of 'Sweet William'. He married Joan daughter of William Bonham the stationer and had one son Bonham Norton. He died in 1593 aged 66 and his will was proved January 1st, 1594. He left a large fortune in real and personal estate and made considerable bequests to charity. He was buried in the church of St. Faith and his epitaph has been preserved by Dugdale" (p. 112).

20 A Transcript of the Registers of the Company of Stationers of London; 15541640 A.D. Volume II - Text: Entries of Books to 25 June 1595, Entries of Apprentices and Freeman, Calls on the Livery, and Fines to 2 July 1605. Edited by Edward Arber, Assoc. King's Coll., London: F.S.A. Editor of The First printed English New Testament, the English Reprints, and The first Three English Books on America. This Copy is the property of The Library of the Faculty of Advocates. Privately Printed. London: 1 October 1875, p. 249. 
Master Norton / Entered vnto him for his copye, A booke in Englische, intytuled, The marchauntes Avizo, aucthorysed vnder th[e h]andes of both the wardens .vjd./

El autor no había recopilado su libro durante un tiempo inmediatamente anterior a su determinación de publicarlo. En la Dedicatoria afirma que sólo se decidió,

Worshipfull, upon verie earnest motion \& persuation of a friend unto me, to set foorth in publick this matter, which I onely had made priuate for instruction of me and mine.

El hijo de John Browne no fue ciudadano de Bristol hasta $1582 \mathrm{y}$, con toda probabilidad, estuvo aprendiendo el oficio, en calidad de sirviente o aprendiz, de 1575 a 1582. No debemos descartar la hipótesis de que el padre recogiera en el libro el material que le había suministrado para su formación durante aquellos años.

Hemos de reparar, igualmente, que la mayor parte de la contabilidad y de las cartas, incluidas en The Marchants Avizo, se refieren a los negocios de Thomas Aldworth y su sirviente, "R.A." que, está claro, que todavía era un mercader en formación cuando se escribieron los documentos. Nos parece razonable asumir que el tal "R.A." era Robert Aldworth, sobrino y aprendiz de Thomas Aldworth. Robert Aldworth inició el aprendizaje con su tío el 20 de Abril de 1577, e ingresó en el gremio de mercaderes de Bristol el 10 de diciembre de 1584. Si damos por bueno que las cartas y documentos relativos a R.A. son copia de las que él escribió o envió, podemos establecer la fecha, de al menos parte del libro, entre 1577 y 1584.

No existe ninguna referencia, en The Marchants Avizo, a la unión de los tronos de España y Portugal, en 1580, o al rápido deterioro de las relaciones anglo-españolas a partir de 1585 . Es cierto que la nota a la primera estrofa del poema, dedicado al lector, se refiere, indirectamente a los efectos de la situación política en el comercio, en 1587: "This was spoken when was a long staye of the marchdntes [sic] trade, to the great decay of many a one", pero, fuera de esta aclaración, el autor no indica que el comercio estuviera en crisis. La ausencia de otras referencias a los sucesos, que debieron causar gran preocupación a aquéllos dedicados al comercio con España, puede encontrar una explicación en el hecho de que no deseaba decir nada que fuera a ofender en el extranjero. La omisión de todo tipo de comentario a los desafortunados enfrentamientos 
políticos, tiene justificación en su cautela y en su tacto. Por otra parte, si aceptamos que la mayor parte del libro se recopiló en los últimos años de la década de los setenta y primeros de los ochenta del siglo XVI, no se requiere semejante argumentación, pues el comercio entre Inglaterra y la Península Ibérica atravesaba momentos de relativa bonanza.

Cuando John Browne empezó a considerar qué clase de material ayudaría a los jóvenes mercaderes a aprender su profesión, es posible que lo primero en lo que pensó fueran cartas, contabilidad y documentos mercantiles. Con este propósito, bien podía haberse servido de su imaginación para confeccionar ejemplos útiles, o seleccionado y editado parte de sus archivos comerciales. Lo que, en realidad, parece que hizo, fue utilizar los documentos comerciales de su amigo Thomas Aldworth. Es verdad que no lo podemos afirmar con seguridad, pero las cartas y otros documentos de The Marchants Avizo poseen el aroma de ser fruto de transacciones reales; además, los nombres de los barcos y las iniciales de algunas personas corresponden a embarcaciones e individuos del Bristol isabelino, lo que explica que muchos documentos estén firmados con las iniciales "T.A." (Thomas Aldworth) y "R.A." (Robert Aldworth) y no con las de John Browne, o su aprendiz. Y, al mismo tiempo, nos aclara la observación que John Browne hace en la Dedicatoria del libro:

Mine own labour or skill I confesse, is but very little or nothing in this thing, because I myselfe do but only as a poore willing labourer, to helpe forwards that worke, the foundation \& platforme wherof, is setled and builded alreadie.

Así pues, parte del contenido de The Marchants Avizo se fundamenta en la documentación de Aldworth. Es posible que John Browne seleccionara lo que necesitaba, lo editó, y le puso las fechas que aparecen impresas en el libro. A esto añadió, en uno de los apartados, el material relacionado con pesos, medidas y monedas, asuntos que le eran muy familiares por sus propias actividades mercantiles:

\title{
CERTAINE ESPECIALL BRIEF NOTES OF WAIGHTS,
}

\author{
measures and value of monies in Portingale, Spaine and \\ France, with an instruction for the better knowledge of \\ diuers wares in those countreyes. \\ Of the Kintal or hundred weight of Portingale, Spaine \\ or France.
}


Igualmente, se sirvió de sus conocimientos y experiencia para dar instrucciones sobre cómo apreciar la calidad de varios productos con los que, con toda probabilidad, el joven mercader tendría que negociar "A BRIEFE INSTRVCTION FOR THE Better Knowledge of certaine wares of Portingale, Spaine and France".

Después de este encabezamiento, ofrece advertencias sobre los productos siguientes: pimienta, clavo, macia, canela, nuez moscada, jengibre, azúcar, calicó, sal, cochinilla, aceite, jabón, glasto, hierro y vino.

Por lo que se refiere al apartado de su obra titulado "HERE FOLLOWE CERTAINE GODLY SENTENCES necessarie for a youth to mediate vpon" y a las recomendaciones sobre moralidad y conducta religiosa, "THE CONCLVSION, WHICH IS an historie very profitable and delightful for a youth to reade and meditate", John Browne pudo servirse de la literatura y sermones contemporáneos, así como de su propia experiencia de la vida; y hasta es posible que practicara la poesía y la narrativa con el fin de escribir los versos del principio del libro y la "profitable and delightful history" del final. Escribió los versos, como muy pronto, en 1587, y la Dedicatoria está firmada "From my house in Bristow the 26. day of October. 1589". Ya tenía impresor, Richard Field, pues William Norton había registrado la obra, en la Stationers' Company de Londres, tres semanas antes, según hemos visto al inicio de este apartado. Es probable que John Browne mantuviera una relación personal con el editor, dado que William Norton era hijo de Andrew Norton, natural de Bristol. De este modo, esta interesante recopilación, que hasta entonces sólo la conocía un círculo restringido de Bristol, fue accesible a muchas más personas. La palabra española avizo, que aquí significa información, o advertencia, se incorporó, a nuestro juicio, de forma apropiada, al título del libro.

Gordon Connell-Smith, en su obra Forerunners of Drake: $A$ Study of English Trade with Spain in the Early Tudor Period ${ }^{21}$, aporta información esencial para comprender la organización y funcionamiento del comercio anglo-español durante los primeros años de la época Tudor,

21 Gordon Connell-Smith, Forerunners of Drake: A Study of English Trade with Spain in the Early Tudor Period, Longmans, Green and Co., London, 1954. 
y el papel que desempeñó una figura injustamente olvidada: el factor ${ }^{22}$. La inmensa mayoría de los factores eran agentes a comisión, que recibían una "provishon" de dos y medio por ciento. El Dr. Connell-Smith sostiene que:

The employment of commission agents seems to have been a common practice of the merchants conducting business with Spain in the early Tudor period, although there is record of prosperous English merchants sending their sons and even promising young men of little experience to Spain as factors. It was obviously more advantageous to employ established merchants with experience of Spanish business methods and good connections in Spain to handle merchandise on a commission basis ${ }^{23}$.

Abundando en esta idea, nos ofrece ejemplos, como el "rake's progress" de Robert Harvey, un muchacho de Plymouth, enviado a España por Richard Field "to lerne the ffashyon and maner of those parties/ in the cowrse of marchaundise"24. Harvey, al parecer, se dedicó a la buena vida:

Several of the merchants present on the voyage declared in evidence that the young factor was constantly drunk and at various ports of call spent money lavishly upon entertainment (...). At the Portuguese capital (...), Harvey went ashore and while he was there his ducats were stolen ${ }^{25}$.

Al llegar a Sanlúcar de Barrameda, lo sucedido se puso en conocimiento de James Fitzjames, "Judge of the Englis nacyon", del cónsul y del vicecónsul, Edward Lewis ${ }^{26}$. Como resultado de las investigaciones, dos marineros fueron encarcelados, aunque poco después los pusieron en libertad. Nada llegó a saberse del paradero de los ducados de Harvey. Su comportamiento no terminó con su carrera de mercader, pues en el Archivo de Protocolos de Sevilla se conservan pruebas documentales de sus transacciones comerciales en Andalucía años más tarde de lo acaecido ${ }^{27}$.

22 J. Lanero Fernández y E. Ortega Montes, "De aprendiz a mercader: El factor en el comercio internacional inglés del siglo XVI", Pecvnia, 5 (2007), pp. 145-180.

23 Gordon Connell-Smith, op. cit., p. 23.

24 Ibid., p. 13. Cfr. Public Record Office, High Court of Admiralty, Examinations, 2, 13 October 1537.

25 Gordon Connell-Smith, opus cit., pp. 13-14.

26 Cfr. Public Record Office, High Court of Admiralty, Examinations, 2, 3 July 1537.

27 Archivo de Protocolos de Sevilla, Oficio XV, 1545, Libro II, ff. 139v, 140, etc. 
Pero no todos los jóvenes debieron ser tan irresponsables como Harvey, pues, los mercaderes de Bristol continuaron confiándoles gran parte de sus negocios. The Marchants Avizo estaba ideado para estos muchachos más que para los agentes a comisión. Se dirigía, sobre todo, a los factores que todavía estaban en período de aprendizaje y que iban a salir por primera vez al extranjero, al servicio de sus patronos.

Poco más conocemos de la formación de estos mercaderes en ciernes del Bristol isabelino. Una gran mayoría de estos jóvenes pertenecía a familias acomodadas y es de suponer que recibían una educación general antes de convertirse en aprendices. Es posible que muchos de ellos fueran a la Bristol Grammar School, dato que no podemos afirmar con seguridad, pues los archivos de la escuela, de aquella época, no se conservan.

El período de aprendizaje duraba, al menos, siete años; no obstante, era frecuente que el joven se viera obligado a permanecer algún tiempo más. Podía convertirse en "free-man", como muy pronto, a los veintiún años. Es probable que los mercaderes prefirieran que sus aprendices iniciasen su profesión con más edad que la que, por otra parte, era la acostumbrada para los artesanos y trabajadores manuales. Hay que tener en cuenta que Robert Aldworth ya tenía dieciséis años y medio cuando comenzó su aprendizaje con su tío el 27 de abril de 1577. Desconocemos qué clase de educación había recibido antes de emprender su carrera comercial. Puede que fuera a la escuela en Londres, donde su padre, Richard Aldworth, era un afamado mercader. Robert debía haber realizado un aprendizaje de diez años de duración; en realidad se le permitió convertirse en ciudadano de Bristol el 10 de diciembre de 1584 cuando tan sólo había servido poco más de siete años y medio. Tenía veinticuatro años.

Parece razonable suponer que el aprendiz de un mercader recibiría instrucción, en primer lugar, sobre algunos aspectos del comercio, en la casa de su patrón, donde tendría la oportunidad de familiarizarse con las técnicas comerciales de la época y aprender algo de los productos con los que tendría que negociar. Luego, si era un joven que prometía, y se había adaptado a la perfección, podía ser enviado al extranjero para actuar como agente de su patrón. Este período de práctica fuera del país era de valor incalculable. Le aportaba conocimientos y confianza en sí mismo; al tiempo que su primera experiencia sería una buena prueba para demostrar si tenía el carácter y la habilidad para triunfar en una profesión que no era precisamente sencilla. En palabras de John Wheeler, Secretario 
de la Society of Merchants Adventurers of England ${ }^{28}$, le permitía "to learn good fashions, and to gain experience and knowledge in trade and the manners of strange nations, the better to know the world betimes".

Estos viajes de negocios al extranjero tenían otra ventaja para el aprendiz. Su principal función era realizar transacciones comerciales en representación de su patrón; pero, de lo que se desprende de The Marchants Avizo, por cada operación recibía una "prouision" o comisión de dos y medio por cien. Además, con el permiso de su patrón, podía realizar sus propios negocios, posiblemente con capital suministrado por su familia o amigos. También estaba autorizado, contando asimismo con el consentimiento de su patrón, a actuar de representante a comisión de otros mercaderes. Así las cosas, tenía oportunidades considerables para reunir el dinero que necesitaría en el futuro, cuando se estableciera por su propia cuenta. Hay constancia de que, en el siglo siguiente, se dieron coyunturas excelentes para que los jóvenes pudieran hacer dinero de este modo, y que los mercaderes londinenses exigían fuertes cantidades a los aprendices que enviaban al extranjero. Que la situación era razonablemente buena, a finales del siglo XVI, es un aspecto fácil de deducir por el mero hecho de que el autor de The Marchants Avizo insiste en que el aprendiz debe mostrarle las cuentas de sus propios negocios y no debe cargarse con mucho trabajo de otros, en detrimento de los intereses de su patrón:

See that at no time you do take any mans doings or dealings into your hands, without my leaue and counsell: because by the trouble of other mens businesse, you may neglect \& frustrate mine owne. And haue also regarde, for those small aduentures which I shall licence you to make for your owne priuate benefict, that euery voiage you do deliuer me an accompt of it, wherby from time to time I may see and know your estate, and what of right doeth aperteine vnto you ${ }^{29}$.

Por lo tanto, el joven que se embarcaba para su primera empresa en el extranjero, tenía la ocasión de prestar un buen servicio a

28 A Treatise of Commerce. Wherein are shewed the commodities arising by a well ordered and ruled Trade, such as that of the Societie of Merchants Aduenturers is proued to be: Written principally for the better information of those who doubt of the Necessarinesse of the said societie in the State of the Realme of England. By lohn Wheeler, Secretarie to the said Societie. Printed at London by lohn Harison. 1601. (Esta obra, que contiene una información histórica valiosa, es una defensa elaborada del sistema de la Merchant Adventurers' Company contra las objeciones de los mercaderes hanseáticos y otros oponentes).

29 The Marchants Avizo, ed. cit., fols. 5-6. 
su patrón y a sí mismo. No obstante, debía estar bien instruido si quería cumplir su misión satisfactoriamente. Uno de los instrumentos más importantes de su cometido era el manejo eficaz de la correspondencia. Se sobreentiende que habría aprendido algo al respecto en el establecimiento de su patrón y que estaría familiarizado con los libros de correspondencia de aquél; sin embargo, a juzgar por el tono de The Marchants Avizo, algunos jóvenes debieron perder el tiempo preguntándose qué debían decir o escribiendo párrafos extensos con el fin de redactar epístolas interminables e irrelevantes. En la segunda mitad del siglo XVI, se publicaron manuales de correspondencia que contenían modelos de cartas, pero no estaban ideados para satisfacer las necesidades de los futuros hombres de negocios. Después de la publicación de The Marchants Avizo, les bastaba con consultar sus ocho modelos de cartas para encontrar algo apropiado para la mayor parte, si no todas, de las ocasiones:

A letter to send to his maister when he is forced by weather into any Port upon his voyage.

A letter to be sent presently upon his arriuall at his Port.

$A$ letter to be sent next after his first letter that he wrote of his arriuall.

Folio

A letter to be sent from his second Port of arriuall.

$A$ letter to be sent in that shippe where he hath laden goods.

A letter to be sent unto one that hath left some businesse to do under your hands.

A letter of thankes to a friend that hath done you some pleasure: wherein you also request againe some farther good turne of him.

A letter to desire the goodwill of a friend to helpe you in some matter of your businesse.

Angel Day, autor de The English Secretorie ${ }^{30}$, consideró la obra "most fully and amplie suffizing" para instruir a un sirviente o factor en las formas de tratamiento de su patrón, según recoge, con acierto,

30 Angel Day, The English Secretorie, wherein is contayned a perfect method, for the inditing of all manner of epistles and familiar letters, together with their diuersities, enlarged by examples vnder their seuerall tytles. In which is layd forth a Path-waye so apt, plaine and easie, to any learners capacity, as the like whereof hath not any time heretofore beene deliuered. Nowe first deuized, and newly published, by Angel Daye. Altior fortuna Virtus. At London, Printed by Robert Walde-graue, and are to be solde by Richard lones, dwelling at the signe of the Rose and the Crowne, neere vnto Holburn Bridge. 1586 / R. Jones for C. Burbie, 1592. 
Jean Robertson en su obra, The Art of Letter Writing. ${ }^{31}$ La primera parte de The English Secretorie se publicó en 1586; la segunda, no vio la luz hasta 1592. En esta última, al presentar el modelo de carta "From a seruant or a factor to his maister", nos dice Angel Day:

In the writing of the last Letter, there was shewed me by the Printer, a book called the Marchants Auiso, helping and in mine opinion most fully and amplie suffizing to his instruction ${ }^{32}$.

Es de esperar que los jóvenes no hicieran demasiado caso de la frase "Little newes I heare worth the writing" y que no pasasen por alto la indicación posterior: "Here write your news if you have any".

Uno de los puntos que más destaca The Marchants Avizo es la obligación que tenía el sirviente de mantener informado a su patrón del desarrollo de sus operaciones y del estado del mercado en el extranjero. Si el barco se detenía en un puerto a causa de vientos desfavorables, el patrón debía estar informado. Tan pronto como llegara al puerto de destino, se debía enviar una carta a través de la primera embarcación que regresara a Inglaterra. Esta información era vital "because it is the thing that euerie Marchant doth especially long after to vnderstand"33. El miedo a los naufragios, la piratería, y a los innumerables peligros del mar, debió dar muy malos ratos, y muchas noches sin dormir, a los mercaderes de Bristol de finales del siglo XVI. En una época de comunicaciones lentas, era esencial que el mercader tuviera, tan pronto como fuera posible, cualquier información que pudiera afectar a la buena marcha de su negocio.

Entendemos que el joven mercader recibía muchos consejos de su patrón antes de hacerse a la mar y que, con toda seguridad, llevaba consigo instrucciones concretas del tenor de las que recoge The Marchants Avizo bajo el encabezamiento ${ }^{34}$ : "A GENERALL REMEMBRANCE FOR A

31 Jean Robertson, The Art of Letter Writing: An Essay on the Handbooks Published in England During the Sixteenth and Seventeenth Centuries, University Press of Liverpool, 1942.

32 The English Secretorie (1592), p. 62.

33 The Marchants Avizo, fol. 2. El autor, anónimo, de A Speciall Direction for Divers Trades, c. 1575-85, destaca la importancia de que el mercader esté informado de lo que sucede en el extranjero: "Therefore adverticement is good and the principall thinge that belongeth to A Merchaunte". Cfr. R.H. Tawney and Eileen Power, eds., Tudor Economic Documents, Being Select Documents Illustrating the Economic and Social History of Tudor England, 3 vols., Longmans, Green and Co., London, 1924, vol. III, pp. 207-208.

34 The Marchants Avizo, fol. 1. 
SERVANT WHEN HE FIRST trauelleth to the Sea, as to Spaine or Portingale, or other countreyes".

Debía cumplir las recomendaciones precisas que había recibido de su patrón y de otros a los que representaba. Si se le había dicho que comprara cierta mercancía, no debía olvidar lo ordenado y comprar algo más, sencillamente porque pareciera barato. Se le daban unas nociones elementales de la ley de la oferta y la demanda y se le informaba de que:

for ordinarily it falleth out, that the quantities of the best cheape wares that is brought home, hath smaller vtterance and lesse profite, than such deare wares as there commeth but verie little quantitie of ${ }^{35}$.

The Marchants Avizo aconseja al joven aprendiz que busque siempre el consejo de los mercaderes experimentados en lo referente a:

how you are to deale about your wares, both touching the landing it, the customing it, the selling it, the receauing of your moneyes, the buying of any wares againe, the customing the same againe, and to haue out all your writs and dispatches for euery such thing, as is needfull to be had ${ }^{36}$.

Había mercaderes de Bristol residiendo en España y Portugal dispuestos a prestar ayuda a los principiantes, a cambio de una módica compensación económica acorde con estas gestiones rutinarias de los negocios.

Aunque debía obedecer las órdenes que se le habían dado, y debía procurarse el consejo de los que tenían más experiencia que él, era de esperar que el joven aprendiz también se sirviera de su propia iniciativa y sentido común. El comercio exterior era un arte, no una ciencia, por lo que el muchacho debería tomar decisiones en asuntos de los que no tenía órdenes precisas. Al hacer una venta se le recomendaba que

...lightly doe not refuse the second or third chapmans offer: for most ordinarily it falleth out, that the first and fourth offer is neuer so good as the third offer: but in this you are to haue a good insight your selfe, and to do according as is your hast and necessitie for your sales ${ }^{37}$.

\footnotetext{
35 Ibid., fol. 4.

36 Ibid., fol. 3.

37 Ibid., fol. 5.
} 
Una de las partes más importantes del arte del mercader consistía en valorar con exactitud la calidad de los vinos, especias, paños y otras mercancías que estaban a la venta. Una mala tasación podía significar pérdidas desastrosas para el patrón, con lo que este aspecto de su trabajo debía poner en tensión a un joven que, probablemente, asumía, por primera vez en su vida, toda la responsabilidad. Una valoración correcta dependía de la experiencia y de la habilidad que se tuviera para estas cosas. Es indudable que el aprendiz habría adquirido algunos conocimientos en el almacén de su patrón, si bien el autor de The Marchants Avizo le ayuda todo lo que puede dándole un conjunto de reglas generales que le sirvieran para tomar una decisión. Así, bajo el encabezamiento "A BRIEFE INSTRVCTION FOR THE Better Knowledge of certaine wares of Portingale, Spaine and France" ofrece una descripción detallada de los siguientes productos: pimienta, clavo, macia, canela, nuez moscada, jengibre, azúcar, calicó, sal, cochinilla, aceite, jabón, glasto, hierro, aceite de pescado y vino. Veamos las características que, según el autor, deben tener los vinos de calidad:

Of wines: it cannot be set downe by pen or words, the right knowledge of it, for it is perciuable only by the taste and fauor. But the best sorts of wines generally are, when they doe tast pleasant and strong withall and when they drinke cleane and quicke in the pallet of the mouth, and whe the are cleere \& white hued if they be white Wines, or of faire orient red, if they be red wines. But if they drinke weake, rough, foule, flat, inclining to egernesse, or long: they are not good ${ }^{38}$.

La contabilidad constituía, necesariamente, una parte importante del trabajo de los mercaderes. No cabe duda de que el joven habría recibido formación contable de su patrón y, es muy posible que conociera los tratados de teneduría de libros que se publicaron en Inglaterra, en la segunda mitad del siglo $\mathrm{XVI}^{39}$ :

OLDCASTLE (Hugh)

A Profitable Treatyce called the Instrument or Boke to learne to knowe the good order of the kepyng of famouse reconynge called in Latyn, Dare and Habere,

$38 \quad$ Ibid., fol. 27.

39 Cosmo Gordon, Bibliography of Book Keeping, vol. II of the catalogue published by the Institute of Chartered Accountants in England and Wales, 1937. H.W. Thomson and B.S. Yamey, "Bibliography of Book-Keeping and Accounts-1494 to 1650", Accounting Research, October 1958. 
and in Englyshe, Debitor and Creditor. London, John Gough, 1543.

\section{YMPYN CHRISTOFFELS (Jan)}

A Notable and very excellente woorke, expressyng and declaryng the manner and forme how to kepe a boke of accōptes or reconynges, verie expedient and necessary to all Marchantes, Receiuers, Auditors, Notaries, and all other. Translated with greate diligence out of the Italian toung into Dutche, and out of Dutche, into french, and now out of frenche into Englishe. London, Richard Grafton, 1547.

\section{PEELE (James)}

The Maner and fourme how to kepe a perfecte reconyng, after the order of the moste worthie and notable accompte, of Debitour and Creditour, set foorthe in certain tables, with a declaration therunto belongyng, verie easie to be learned, and also profitable, not onely unto suche, that trade in the facte of Marchaundise, but also unto any other estate, that will learne the same. 1553. Imprinted at London, by Richard Grafton, printer to the Kinges Maiestie. Cum priuilegio ad imprimendum solum.

The Pathwaye to perfectnes, in thaccomptes of Debitour and Creditour... London, T. Purfoot, 1569.

\section{WEDDINGTON (John)}

A Breffe Instruction, and manner, howe to kepe, marchantes bokes, of accomptes. After the order of debitor and creditor... Andwarpe, Petter van Keerberghen, 1567.

\section{MELLIS (John)}

A Briefe Instruction and maner how to keepe bookes of accompts after the order of Debitor and Creditor, \& as well for proper accompts partible, \& c. By the three bookes named the Memoriall, Journal \& Leager, and of other necessaries appertaining 'to a good and diligent marchant... Newely augmented and set forth by John Mellis. London, John Windet for Hugh Singleton, 1588.

A pesar de los tratados publicados que acabamos de citar, John Browne estimó oportuno facilitar a sus lectores modelos contables apropiados para el trabajo que iban a emprender. Estas cuentas consisten 
en anotaciones sencillas de ventas y compras, en las que se detallan los gastos de cada una de las transacciones. Al aprendiz se le había enseñado un método sencillo de calcular su comisión de dos y medio por cien, y el sistema para convertir la moneda portuguesa en española. Las cuentas individualizadas en toda una serie de operaciones, que incluían ventas y compras, se resumen, finalmente, en una "Account Currant" que tiene referencias cruzadas a los folios en los que se recogen los detalles pormenorizados de las transacciones ${ }^{40}$ :

$\begin{array}{ll} & \text { Account } \\ \text { Marchants Aviso } & \text { Currant }\end{array}$

The 1o. day of Ianuarie. 1589

My master Alderman Aldwoorth, merchant of the cittic of Bristow, oweth 13I.V.326 Res of Portugal monies, which being reduced into Spannish Meruedis make 123.V.118. Mer. for so much cost with all charges of 6 kintals of Pepper as appeareth more at large, Folio 34

More oweth 108.V.514 Res, which in Spanish Meruedis is IOr.V.73I Mer. for so much cost with all charges 2 Kintals of Cloues: 3. Roues of Mases, \& one kintall 2. Roues of Synamon, as appeareth more at large Fol. 35 …......................... More, oweth I33 V. $976 \mathrm{Mer}$. for so much cost with al charges 10. pipes of Oyle: as appeareth more at large: Fol. 36 More oweth $x$ 1 1.V.508 Meruedis, for so much cost with all charges 20 Buttes of Sacke, as appeareth more at large. Fol.

37 More oweth 914. Meruedis for registring the billes of exchange in Cyuill, and recouering the monies which is one

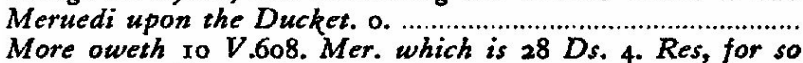
More oweth ro V.608. Mer. which is $28 D_{s}$. 4. Res, for so appeareth by the particular account thereof, which I will deliuer you. 0 ... Item 1 40. V.6ro. Mer. (which is 376. Duckets lesse Meru) resteth to ballance this account: for the which I will be countable vnto you at the sight hereof.

Nore heerein the account currant: that your must bring all your portingall (Res) into Spanish (Meruedis) which is onely to multiplie your some of Res, by the number of

Mul. I5 I5. and so to diuide the multiplier of that, by the number of

Deu. 16 I6 and that maketh it into Meruedis. This is a principall rule, \& it were too long to yeeld the plaine reason of it. But note withall, that you must account after 375 . Mer. to the spanish Ducket: which one Meruede is commonly allowed to the Factor of the recouer of the monies.

40 The Marchants Avizo, fols. 46-47. 


$\begin{array}{rr} & \text { Account } \\ \text { Marchants Aviso } & \text { Currant }\end{array}$

\begin{tabular}{|c|c|}
\hline & \\
\hline \multicolumn{2}{|l|}{ The Io. day of Ianuarie 1589 . } \\
\hline $\begin{array}{l}\text { My master Alderman Aldworth marchant of the cittic of } \\
\text { Bristowe, is due } 238 \mathrm{~V} \text {. 159 Res of Portingall monies: which } \\
\text { being reduced into Spanish Meruedis, maketh } 223 \text { V.274 } \\
\text { Meruedis, and is the Neate of ro. fine brode clothes, one } \\
\text { Stammell and a wrapper: as appeareth more at large. Fol. }\end{array}$ & \\
\hline $\begin{array}{l}30 \text { mell and a wrapper: as appeareth more at large, Fol. } \\
\text { More is due } 127 . V .96 \mathrm{r} \text {. Res. which in Spanish Meruedis is }\end{array}$ & $\begin{array}{r}M e r \\
000 . M .223 . V .274\end{array}$ \\
\hline 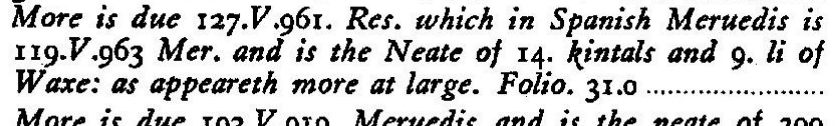 & $000 . M .119 . V .963$ \\
\hline $\begin{array}{l}\text { More is due 192.V.9ro. Meruedis, and is the neate of } 300 \\
\text { Kintals and 10. pound of Lead, as appeereth, Folio. } 32 \text {........ }\end{array}$ & $000 . M .192 . V .910$ \\
\hline $\begin{array}{l}\text { More is due } 86 . V .318 \text { Meruedis: and is the neate of } 20 \text { peeces } \\
\text { of Bayes, as appeareth, Fol. } 33\end{array}$ & $000 . M .086 \mathrm{~V} .318$ \\
\hline Summe to & $\begin{array}{r}M e r \\
0 n M .622 . V .465\end{array}$ \\
\hline
\end{tabular}

Note that you still obserue, to keepe a copie of euerie marchants account that you deale for: for so will it be auailable for you, if you should be called in question againe, about your account.

$\{$ Thus endeth the Account $\}$

Como podemos observar, no hay nada complicado en estas cuentas, aunque en su forma y distribución, desde un punto de vista contable, son más perfectas que las que llevaba Thomas Kitson, factor de Gresham, hacia mediados del siglo $X \mathrm{VI}{ }^{41}$. El objeto de estas cuentas era, sin duda, enseñar al joven a llevar un archivo metodológico de todas sus transacciones en el extranjero, y facilitar al mercader la información que necesitara para incorporarla a sus propios libros de contabilidad. Los detalles que proporcionan las cuentas también servían para recordar al principiante cómo era el proceso de hacer negocios en el extranjero.

Otro dato interesante de estas cuentas es que parecen basarse en el supuesto de que las operaciones mercantiles debían

41 Cfr. John William Burgon, The Life and Times of Sir Thomas Gresham; Compiled Chiefly from His Correspondence Preserved in Her Majesty's State-Papers Office: Including Notices of Many of His Contemporaries, 2 vols., Robert Jennings, 62, Cheapside, London, 1836. Es de singular valor la obra de Raymond de Roover, Gresham on Foreign Exchange: An Essay on Early English Mercantilism with the Text of Sir Thomas Gresham's Memorandum for the Understanding of the Exchange, Harvard University Press, Cambridge, Mass., 1949. Para una biografía más sintética que la de Burgon, véase F.R. Salter, Sir Thomas Gresham (1518-1579), Leonard Parsons, London, 1925. 
efectuarse en metálico. Al factor no se le había explicado cómo anotar las transacciones realizadas a crédito. Puede ser que John Browne no desease complicar demasiado las cosas al principiante; pero es igualmente posible que el sistema crediticio fuera poco usado en el comercio español y portugués, en comparación con su papel destacado, por ejemplo, en el holandés.

Otra sección que resalta en The Marchants Avizo, es la que presenta al lector ejemplos de documentos mercantiles al uso en aquella época. Hemos de destacar una póliza de seguros, para el barco Gabriel, sacada por Thomas Aldworth y suscrita por dos mercaderes londinenses y un tercero de Bristol $^{42}$ :

\section{A Policie or writing of assurance}

$\mathrm{N}$ the name of God Amen. Be it known vnto all men by these presents: that Thomas Aldsworth marchant of the citie of Bristowe doth make assurance and causeth himselfe to be assured from the Port of the sayd citie of Bristow called Hungrode vnto the port of Lisbon in the kingdome of Portingale, and therehence directly backe againe to the aforesayd Port of Bristow: vpon the bodie, tackle, apparell, ordinance, munition, artillerie, boate, and other furniture, of the good ship called the Gabriell of Bristow, of the burthen of 6o. tunnes, or thereabouts. And also vpon all goods, wares, and marchandises laden or to be laden in the aforesayd ship the Gabriel, whereof is maister vnder God for this present voyage R.M. or by what other name the maister of the ship may or shal be called. Beginning the aduenture from the day and houre of the lading of the anker, spreading the sayle, and departure of the sayde ship from Hungrode aforesaid. And so shall continue and endure vntill such time as the said ship with all her sayd furniture, \& all the goods and marchandises laden in her, shall returne and safely arriue back againe from Lisbon vnto the Port of Hungrode aforesayd, \& there hath surged and mored at an anker by the space of 24 . houres in good safetie. Touching the aduentures and perils which we the assurers hereafter named are contented to beare and take vpon vs this present voyage, are of the seas, men of warre, fire, enemies, pirats, rouers, theeuves, Iettesons, letters of marke and countermarke, arrests, restraints, and detainments of Kings and Princes \& of all other persons, barratry of the Master and mariners, and of all other perils, losses, \& misfortunes whatsoeuer they be, or howsoeuer to the damage or hurt of the sayd Ship and goods or any

42 The Marchants Avizo, fols. 56-59. 


\begin{abstract}
part or parcell thereof. And that in case of any misfortunes: it shall then be lawfull to the assured his factor, seruant, or assigne, to sue labour, \& trauail, for in and about, the defence, safgard and recouerie of the said Ship \& goods, and all other the premisses, without any preiudice to this assurance. To the charges whereof, we th'assurers shal contribute eche one according to the rate and quantity of his summe herein assured. It is to be vnderstood that this present writing and assurance shallbe of as much force, strength \& effect, as the best and most surest policie or writing of assurance which hath bene euer heretofore vsed to be made in Lumbard streete, or now within the Roial exchange in London. And so we the assurers are contented, and doe promise and bind our selues and euerie of vs, our heirs, executors and assignes for the true performance of the premises, according to the vse and custome of the said streete, or Royall exchange. Confessing our selues to be fully satisfied and paied of and for the considerations due vs after the rate of 7 . upon the 100. And in testimony of the truth, we the assurers haue hereunto seuerally subscribed our names and summes of money assured, giuen in London the 19. day of September. I589.

I W.N. marchant of London am content with this assurance 25.li (which God preserue) for 25. pounds this 19. day of

September. 1589.

I R.T. marchant of London am content with this assurance 25.li (which God preserue) for 25. pounds this 20. day of September. 1589 .

I M.R. marchant of Bristow am content with this assurance 25.li (which God) preserve for 15 . pounds this 2r. day of September 1589 .
\end{abstract}

También recoge dos modelos de letra de cambio: uno para España y otro para Inglaterra. El primero adopta la forma de una orden de pago, en la que puede verse la influencia de los métodos comerciales italianos ${ }^{43}$ :

The forme of a bill of exchange for the countrey of Spaine.

WOrshipfull: may it please you to pay vpon this my first bill vnto R.N. or the bearer hereof, within 15. dayes after the safe arriual of the Gabriell of Bristow to her Port of discharge: *thirtie "Nose that you arriual of the Gabriell of Bristow to her Port of discharge: "thircie must make 3. of roo. these billes. Duckets that I haue vp by exchange for your vse of T.M. a marchant *Thirty and thre of London at six shillings and eight pence the Ducket. From S. pound six shillings Lucar the i6. day of December, 1589

By me R.A.

$43 \quad$ Ibid., fol. 53. 
El segundo no sigue el formato de una orden de pago, sino de un pagaré, más característico de la Europa del Norte ${ }^{44}$ :

$A$ bill of Exchange to be made in England.

\begin{abstract}
WItnesseth this present bill of exchange: that I R.A. marchant of the citie of Bristowe, do owe vnto T.M. marchant of the sayd citic, the summe of roo. Duckets: I say an hundred Duckets of currant monie of Spaine, accompting after Ir. rials of plate to the Ducket. To be payd vnto the said T.M. or his assignes, within ro. dayes next and immediately after the safe arriuall of the good ship called the Gabriel of Bristowe, to the port of S. Lucar in Andalouzia in Spaine, or any other porte of hir discharge. And for the true payment thereof, I the abouenamed RA. do binde me, my goods my heirs executors, \& assignes, firmly to these presents. In witnesse of the truth, I haue caused two of these billes to be made (the which the one being payed, the other to be voide): and haue put my firme and seale vnto them, \& deliuered them as my deed, in Bristow the 15. day of September 1589. and in the 31. yeare of our Soueraigne, Queene Elizabeth her maiesties raigne, \&c.
\end{abstract}

La colección de formularios no incluye, sin embargo, un contrato de flete, quizá porque el joven mercader no tenía que preocuparse de ese documento al inicio de su carrera.

Era tradicional que el aprendizaje ofreciera mucho más que una mera formación empresarial. La Society of Merchant Adventurers of England, por ejemplo, imponía un código de conducta a sus jóvenes, reconociendo con él su responsabilidad sobre unos muchachos que ya no estaban bajo la tutela de sus padres y se encontraban expuestos a las tentaciones de la vida en una ciudad extraña. No sabemos si la Spanish Company tenía una normativa similar, pero el autor de The Marchants Avizo se tomó muy en serio su responsabilidad en la formación religiosa y moral de los lectores. Hace hincapié en la necesidad de la oración y de la meditación; se recomienda que el joven dedique media hora al día a estos menesteres, con independencia del volumen de trabajo que tenga, al tiempo que se le dan sugerencias de cómo deben ser. Cuando su barco llegaba al puerto de destino, su primer pensamiento debía ser para dar gracias a Dios por haberle protegido. Debía rezar siempre antes de las comidas. Es probable que el autor se sintiera en la obligación de insistir

44 Ibid., fols. 53-54. 
en estas cosas, porque los aprendices iban a países de religión distinta a la suya y donde no había ocasión de asistir a servicios religiosos que estuvieran en concordancia con los de la Iglesia de Inglaterra. John Browne no hace referencia a esto, pues deseaba que su libro no fuera ofensivo en el extranjero, aunque seguramente tuvo ese pensamiento.

The Marchants Avizo ofrece muchos consejos a los jóvenes en el ámbito de la ética empresarial y de la conducta de la vida privada. El aprendiz debía ser "lowly, curteous, and seruiceable vnto euery person" ${ }^{45}$; escrupulosamente honesto; no debía participar en ninguna clase de juegos, y mucho menos si se trataba de naipes o dados; no debía ser ostentoso en el vestir; debía cumplir sus promesas y vivir de acuerdo con sus ingresos. Se le recomendaba:

Be not greedy nor in lust after that, which is both displeasant vnto God: hurtfull to thy body; an enemy to thy soule: and a shortner of thy life: which is: Wine, Welth and Women ${ }^{46}$.

Se le exhortaba a que se apartara del mal y practicara el bien, ayudara a las viudas, los huérfanos, los desconocidos, los pobres y los oprimidos.

Aunque John Browne decidió incorporar la palabra española avizo al título del libro, nos sorprende que no intente inducir a sus lectores a estudiar español o portugués ${ }^{47}$. Se conservan pocas pruebas documentales que nos puedan informar de la predisposición de los mercaderes ingleses a aprender el idioma de los que tenían negocios con ellos. Valga de muestra que, en el siglo XVII, los albaceas de John Whitson, mercaderes de Bristol, hicieron constar que poseía libros en latín, inglés, y uno en español, lo que demuestra que no era frecuente. Suponemos que los mercaderes que vivían en el extranjero, durante algún tiempo, aprendían la lengua, pero la mayor parte de los negocios se realizaba con la ayuda de intérpretes. Puede que John Browne pensara que sus lectores ya tenían bastante que aprender, como para tener que estudiar, además, español o portugués. Algunos, incluso, tenían dificultades con el inglés cuando redactaban algún documento o carta.

45 Ibid., fol. 3.

46 Ibid., fols. 63-64.

47 Dejando a un lado los nombres de las monedas, pesos, medidas y derechos de aduana, tan solo hay una segunda palabra española en el libro: cabo (paquete pequeño). 
The Marchants Avizo contiene tal cantidad de información detallada para el joven mercader, en lo tocante a técnicas comerciales y normas de conducta, que no nos parece lógico que, desde la óptica de nuestros días, señalemos todos los aspectos que nos gustaría encontrar en el libro y que éste no recoge. Por ejemplo, no hay ninguna alusión a la Spanish Company, a la que debía pertenecer todo mercader con negocios en España y Portugal; ni ninguna indicación de si la Compañía poseía algún tipo de organización en el extranjero a la que el joven pudiera dirigirse en caso de necesitar ayuda. Tampoco hay referencia de ninguna clase a las condiciones de vida en España y Portugal: alojamiento, transporte o sistema judicial. Y es inútil intentar encontrar algún tipo de comentario relativo a los deberes del joven en el mar o al llegar al puerto de destino. Del mismo modo, nada se menciona sobre las leyes, nacionales o locales, vigentes en las ciudades españolas y portuguesas. Quizá el autor de The Marchants Avizo pensó que estas cosas se aprendían mejor con la experiencia diaria. Después de todo, su libro es una introducción al tema; pero, aún siendo así, contiene semejante conjunto de datos, que el principiante necesitaba bastante tiempo para asimilarlos.

$\mathrm{VI}$

\section{Edición de 1589}

La primera edición de The Marchants Avizo apareció en 1589, cuando Inglaterra estaba en guerra con España. El único ejemplar que se conserva está en la biblioteca de St. John's College, Oxford, encuadernado con otras obras publicadas entre 1593 y 1681 . La portada es la que reconstruimos a continuación: 


\section{THE \\ MARCHANTS AVIZO \\ VERY NECESSARIE FOR THEIR \\ sonnes and seruants, when they first send them be- yond the seas, as to Spaine and Portingale or. other countreyes. \\ Made by their hartie wellwiller in Christ. I.B. Marchant. ECCLEs. 40.18. \\ To labour and to be content with that a man hath, is a sweet life: but the feare of God is aboue all, \&c.}

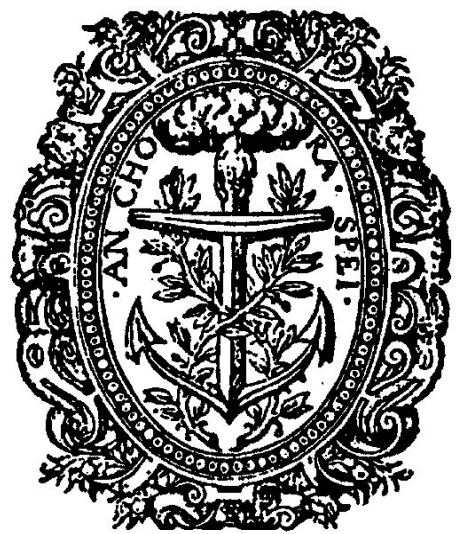

\footnotetext{
Imprinted at London by Richard Field for Wil-

liam Norton, dwelling in Paules Churchyard at the signe of the Queenes armes. 1589.
}

El editor, William Norton (1527-1593) era hijo de Andrew Norton, de Bristol. Fue uno de los socios fundadores de la Stationers' Company de Londres, y responsable de la publicación de un importante número de libros ${ }^{48}$.

48 E. Gordon Duff, A Century of the English Book Trade. Short Notices of All Printers, Stationers, Book-Binders, and Others Connected with It from the Issue of the First Dated Book in 1457 to the Incorporation of the Company of Stationers in 1557. The Bibliographical Society, London, 1905. En la entrada correspondiente al editor de esta edición dice lo que sigue:

NORTON (William), stationer in London, was born in 1527. He was an original member of the Stationers' Company on its incorporation in 1557 and rapidly rose to a high position. He was collector in 1563 and 1564, Under-Warden in 1569-70 and 1593. He did not print himself but 
El impresor, Richard Field, era hijo de Henry Field, de profesión curtidor, de Stratford-on-Avon. Después de haber realizado su período de aprendizaje con Thomas Vautrollier, ingresó, como socio de pleno derecho, en la Stationers' Company, el 4 de Marzo de 1587. The Marchants Avizo fue uno de los primeros libros que imprimió. Su emblema era el "Anchora Spei", el mismo que Vautrollier había utilizado ${ }^{49}$.

Hay una cita del Eclesiástico, 40.18, en la portada de esta primera edición: "To labour and to be content with that a man hath, is a sweete pleasant life: and that is, to find treasure of all treasures" ("Dulce es la vida del que se basta a sí mismo y del que trabaja, pero más todavía la del que encuentra un tesoro" ${ }^{50}$. John Browne debió pensarlo mejor y

had a very large number of books printed for him by others. His address was the King's, afterwards Queen's, Arms in St. Paul's Churchyard and he used as a device a tun having the letters Nor upon it and a spring of "Sweet William". He married Joan daughter of William Bonham the stationer and had one son Bonham Norton. He died in 1593 aged 66 and his will was proved January 1st, 1594. He left a large fortune in real and personal estate and made considerable bequests to charity. He was buried in the church of St. Faith and his epitaph has been preserved by Dugdale (p. 112). Véase también The Dictionary of National Biography.

49 R.B. McKerrow, ed., A Dictionary of Printers and Booksellers in England, Scotland and Ireland, and of Foreign Printers of English Books 1557-1640. The Bibliographical Society, London, 1910. En la entrada correspondiente al impresor de esta edición, se recoge lo siguiente:

FIELD (Richard), printer in London, 1579-1624; (I) Blackfriars, (2) The Splayed Eagle, Great Wood Street, c. 1600. Son of Henry Field, tanner, of Stratford upon Avon, whose goods and chattels John Shakespeare, the poet's father, with two others was employed to value on August 25th 1592. In 1579 Richard Field left Stratford and, coming to London, apprenticed himself to George Bishop for seven years. He was at once transferred for the first six years to Thomas Vautrollier, the Huguenot printer in Black friars [Arber, ii, 93]. Thomas Vautrollier died before March $4^{\text {th }}, 158^{6}{ }_{7}$, and Richard Field who had taken up his freedom on February $6^{\text {th }}$, married his master's widow within a twelvemonth and thus succeeded to one of the best businesses in London. His first book entry is found in the Registers under December $24^{\text {th }}$, 1588. On April 18 ${ }^{\text {th }}$, 1593, Field entered in the Registers "a booke intituled Venus \& Adonis," the first of William Shakespeare's books that passed through the press. On May $9^{\text {th }}$, 1594, Field also printed for John Harrison the elder, Shakespeare's Lucree and a second edition of Venus and Adonis. This was followed in 1596 by a third edition of the same work, in octavo. About 1600 Field removed from Blackfriars to the parish of St. Michael in Wood Street, at the sign of the Splayed Eagle. In 1615 he was returned as having two presses. He became a prominent member of the Stationers' Company, of which he was elected Master in 1619 and 1622 . Field died in the autumn of the year 1624. By his will which was proved on December $14^{\text {th }}$ in that year, he desired that he might be buried in the church of St. Michael, Wood Street. His property he divided into three parts, one of which he left to his wife, who is called Jane in the will. This was probably a second or third wife, and not the Jacqueline, or Jaklin, the widow of Thomas Vautrollier. He bequeathed The Splayed Eagle to his son Richard, and other property in Wood Street to another son Samuel. Small bequests were also left to Manasses and James Vautrollier, two of the sons of Thomas Vautrollier. The only other member of his family mentioned in the will was a sister Margaret, and there is no mention of Stratford upon Avon. Field's business eventually passed into the hands of George Miller, one of his apprentices. [P.C.C., 107, Byrde] Field's principal device was the "Anchora Spei" that had previously been used by Thomas Vautrollier. There were several sizes of it.

He also used most of the borders and tail pieces as well as the types that had belonged to Vautrollier. On the whole his work as a printer was creditable, though it did not approach in excellence that of Vautrollier. It is in his brief connection with Shakespeare that its chief interest lies (pp. 102-3). Cfr. E. Arber, A Transcript of the Registers of the Company of Stationers of London, 15541640, 5 vols., London, 1875-94 para toda referencia a este autor, en la presente y posteriores notas.

50 The Holy Bible, printed at London by Christopher Barker, 1584. 
entender que este pensamiento no era demasiado adecuado para los mercaderes en prácticas, cuyo principal objetivo se supone que era incrementar su riqueza. En ediciones posteriores se utilizaría una cita diferente.

\title{
Edición de 1590
}

El único ejemplar que se conserva es propiedad de Mr. P.E. Tyhurst, de Gatcombe Park, Minchinhampton, Stroud, Gloucestershire, Inglaterra. La portada reza como sigue:

\author{
THE \\ MARCHANTS
}

AVIZO.

VERIE NECESSARIE FOR

their Sonnes and seruants, when they

first send them beyond the Seas, as to

Spayne and Portingale or other Countreyes.

Made by their hartie wellwiller in Christ.

I. B. Marchant.

Eccls. I. Chap. II. verse.

The feare of the Lord is glorie, and gladnes reioycing, and $a$

ioyfull crowne, \& $c$.

Imprinted at London by Thomas Orwin, by the assignes of William Norton.

1590.

En esta portada aparece el emblema del impresor: dos manos que se estrechan, sosteniendo un caduceo y dos cornucopias, rodeados por las palabras: "By Peace Plenty. By Wisdom Peace"51.

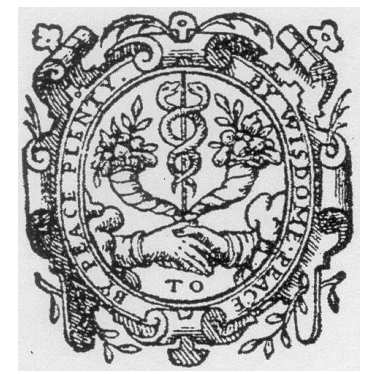

51 Ronald B. McKerrow, Printers' \& Publishers' Devices in England \& Scotland, 1485-1640, The Bibliographical society, 1913, pp. 105-6 e ilustración 273. 
El ejemplar está sin encuadernar y se compone de páginas cosidas, probablemente según lo publicó el impresor. Faltan algunas páginas al final de la obra, que consta de ocho páginas preliminares (portada, dedicatoria, poema e índice), seguidas de sesenta y dos páginas numeradas. La edición de 1589 tiene sesenta y ocho páginas numeradas y la de 1591, setenta. Es posible que la edición de 1590 también tuviera setenta páginas numeradas, pues su presentación se asemeja más a la de 1591 que a la de 1589 y ambas las imprimió Thomas Orwin ${ }^{52}$.

La edición de 1590 no es reimpresión de la de 1589. Alguien, el autor seguramente, aprovechó la oportunidad para hacer algunas modificaciones en el texto y en las marcas de los mercaderes que aparecen en los márgenes.

\section{Edición de 1591}

Tenemos constancia de la existencia de dos ejemplares: uno en la Huntington Library (California); y otro en la New York Public Library. La portada es idéntica a la de la edición de 1590, exceptuando la fecha. Esta edición incluye los preliminares habituales, seguidos de páginas numeradas del uno al setenta. Es muy similar a la de 1590, aunque tiene pequeñas modificaciones que demuestran que no fue una mera reimpresión.

Con la aparición de esta tercera edición, parece que la demanda del mercado quedó satisfecha. Habrían de pasar dieciséis años para que viera la luz la siguiente edición.

52 ORWIN (Thomas), printer in London, 1587-93. In Paternoster Row over against the Cheker. He was an apprentice to Thomas Purfoote, by whom he was presented for his freedom on May $5^{\text {th }}, 1581$ [Arber, ii, 684]. He succeeded to the business of George Robinson, whose widow he married. In 1587-8 Orwin appears to have got into trouble with the Court of Star Chamber, and consequently the Company ordered him to leave off printing until he received the permission of that court; but on May $20^{\text {th }}$ following a letter was received by the Company signed by the Archbishop of Canterbury, the Bishop of London and others, in consequence of which Orwin was admitted a master printer. This incident was referred to by Martin Marprelate in his Epistle, where addressing the Archbishop of Canterbury he says, "Did not your grace of late erecte a new printer... one Thomas Onwine (who sometimes wrought popish bookes in corners: namely, Jesus Psalter, our Ladies Psalter, etc.) with condition he should print no such seditious bookes as Walde-grave hath done?" [Epistle, ed. Arber, p. 23]. According to Cooper in his Admonition, Orwin denied this accusation, but in 1591-2 his press was sized by the Company [Arber, i. 555]. He died before June 25, 1593, being succeeded by his widow Joan Orwin. Orwin sometimes used the device of an urn marked with T.O., at others that of two hands clasping, each other, and the motto "By Wisdom place by peace plenty". A third device was that of Mars standing with sword and shield. Véase R. B. Mackerrow, ed., A Dictionary of Printers and Booksellers in England, Scotland and Ireland, and of Foreign Printers of English Books 1557-1640, ed. cit., p. 208. 


\section{Edición de 1607}

En 1604, España e Inglaterra firmaron la paz. En los años siguientes, el comercio se reactivó. En 1607, John Norton pensó que el libro todavía podía ser de interés, habida cuenta de la nueva situación política angloespañola.

La diferencia más destacable entre esta edición y las anteriores es que el nombre de John Browne ya no figura en la Dedicatoria y ha sido sustituido por las iniciales "J.B."; se ha omitido la frase: "From my house in Bristow the 26 day of October, 1589"; la fecha de "1587" se ha incorporado al margen en el que figura una nota a la primera estrofa del poema; la palabra "king" se ha sustituido por "Queen" en la última estrofa. También hay cambios importantes en los caracteres, ornamentación y ortografía empleados. Sin embargo, poco esfuerzo se dedicó a actualizar la obra. Se sigue exhortando al joven mercader a "Honour thy Prince (sic), for she hath power over life and death". Las cuentas y documentos siguen llevando la fecha de 1589 y en ninguna parte se indica que Thomas Aldworth y John Browne ya habían fallecido.

Hemos podido documentar siete ejemplares de esta edición, que se encuentran en las siguientes bibliotecas: British Museum (Londres); the National Maritime Museum, Greenwich (Inglaterra); the Goldsmiths' Library, University of London (dos ejemplares); the Bodleian Library (Oxford); y the Chaplin Library, Williams College, Williamstown (Estados Unidos). El séptimo es propiedad de Messrs. Page \& Co., Solicitors, 2, Bristol Chambers, Bristol (Figura 1).

El emblema del impresor en esta portada es el de las manos que se estrechan y las cornucopias; el mismo de las ediciones de 1590 y 1591.

Uno de los ejemplares de la Goldsmiths' Library, University of London, está encuadernado con obras del siglo XVII. Le falta la portada; en su lugar, se ha insertado una reproducción facsímil. La portada original puede que sea la que se conserva en la Bagford Collection de la British Library ${ }^{53}$.

El ejemplar de Messrs. Page es el que en su día perteneció al Teniente Coronel Bramble, cuyos comentarios a esta edición se recogen

53 Harley 5949 No. 167 fo. $65 v$. 
en The Proceedings of the Clifton Antiquarian Club, de noviembre de 1892, y a los que ya nos hemos referido en el presente estudio ${ }^{54}$. El ejemplar del National Maritime Museum proviene de la colección del Lowther Castle, en Penrith (Inglaterra), propiedad del Conde de Lonsdale.

Figura 1: The Merchants Avizo. Edición de 1607

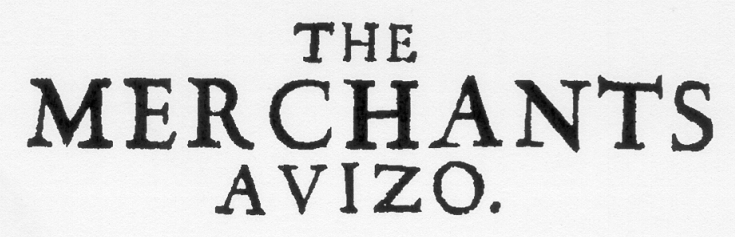

UERIE XECESSARIE FO? their Sons and Seruants, when they firt fend them beyond the Seas, as to Spizize aisd partingale, or other Cosestrics.

CMade by their heartie welwiller in Cbrift, I. B. Merchant.

Ficlel.1. Chap.sx.teres.

The feare of the Lord is glorie, and giadncs, anc reioycing, and a joyfull crowne, \& 2 .

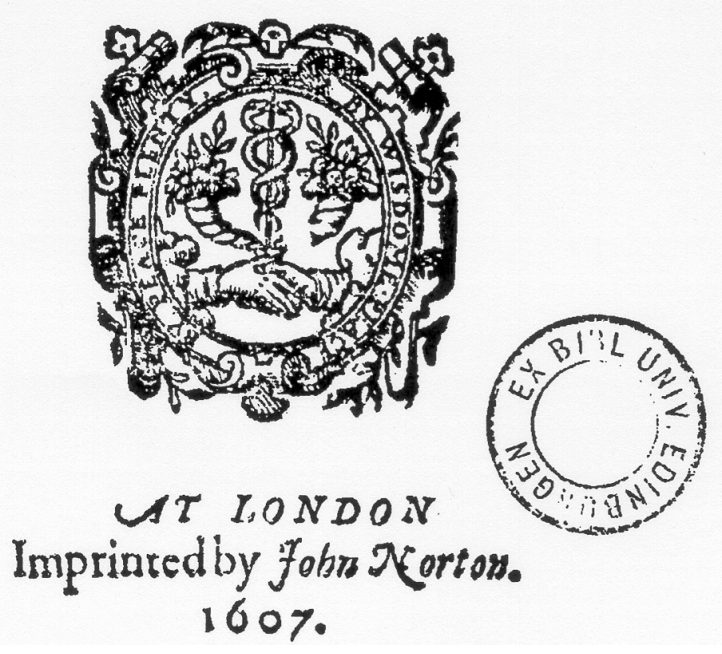

$54 \quad$ Véase nota 3. 


\section{Edición de 1616}

En 1616, John Bill ${ }^{55}$, socio de Norton, sacó a la luz otra edición. Tenemos prueba documental de la existencia de ejemplares en las siguientes bibliotecas: British Museum (Londres); the Bodleian Library (Oxford); Christ Chuch (Oxford); Biblioteca del Congreso (Estados Unidos);

55 BILL (JOHN), King's Printer and bookseller in London, 1604-30; Northumberland House, St. Martin's Lane, Aldersgate Street, and Hunsdon House, Blackfriars. Son of Walter Bill of Wenlock, co. Shropshire. Probably through the influence of the Nortons, also natives of Shropshire, he was sent to London and apprenticed to John Norton, the printer, from the Feast of St. James the Apostle [i.e., July $25^{\text {th }}$ ], 1592, and book up his freedom in 1601. As John Norton was Sir Thomas Bodley's stationer, it was presumably on Norton's suggestion that John Bill was selected by the founder of the Bodleian to travel abroad and buy books for the library on commission. At the same time it speaks highly for his own ability that at the outset of his career he should have been chosen as the best man for such an undertaking. It is uncertain at exactly what period he was abroad, but it was probably between 1596 and 1602 or 1603. In one of his letters Sir Thomas Bodley writes as follows: "You need make no doubt, but Jo. Bill hath gotten everywhere, what the place would afford, for his commission was large, his leisure very good, and his payment sure at home". In another he speaks of Bill as having visited the chief cities in Italy, and as having brought books to the value of upwards of four hundred pounds [Reliq. Bodl., p. 66 et seq.]. After his return home he set up as a bookseller in London, where among his customers was Isaac Casaubon [Pattison's Casaubon, 1875, pp. 406, 433-4]. He had a close and intimate friendship with both John Norton and Bonham Norton; in fact there is very little doubt that he managed the printing business of the former during the later years of his life. There is no doubt also that these three men, John Norton, Bonham Norton and John Bill, advanced the money necessary to enable Robert Baker, the King's Printer, to carry through what is known as the Authorized version of the Bible, and in return for this help some sort of compact was entered into between the parties, by which John Bill and Bonham Norton became shareholders in the King's Printing House. A bitter family quarrel subsequently broke out between Bonham Norton and Robert Parker, and as a result, Robert Parker brought an action in the Court of Chancery against both John Bill and Bonham Norton, which was the forerunner of a long and costly series of law suits. By a decree of May $7^{\text {th }}, 1619$, the Court decided that John Bill was a bona-fide purchaser of his share and was entitled to enjoy it. Consequently he continued to be King's Printer for the remainder of his life. The imprints may be arranged as follows: (I) Robert Barker alone down to July, 1617, (2) Bonham Norton and John Bill from July, 1617, to May $7^{\text {th }}, 1619 ;(3)$ Robert Barker and John Bill from May $8^{\text {th }}$, 1619 , to January, $162_{1}^{0}$; (4) Bonham Norton and John Bill from January, $162_{1}^{0}$, to October 21st, 1629; (5) Robert Barker and John Bill from October 20th, 1629, till John Bill's death on May 5th, 1630. Further evidence that John Bill was carrying on the business of a bookseller at this time is found in the Hist. MSS Comm., 6th Report, where amongst the Manuscripts of the Duke of Northumberland is a list of fifty-three books, mostly foreign books, purchased from John Bill. He also became an extensive publisher of books from 1604 onwards. John Bill regularly visited Frankfort Book Fair and amongst the Domestic State Papers is an interesting letter from him, to Dr. Widemann of Augsburg, dated June 22nd, 1619, relating to some books that Widemann had offered to King James, and which John Bill desired should be sent to the next Frankfort Fair for his inspection [Library, March, 1900, p. 175]. For some years John Bill issued an edition of the Frankfort catalogue for circulation in England, and all the issues from 1622 to 1626 contained a special appendix of Books Printed in English [ibid.]. John Bill made his will on April $24^{\text {th }}, 1630$, and died shortly afterwards. He bequeathed a sum of $\mathrm{f} 15$ to the poor of his native place, and a sum of $\mathrm{£} 10$ to pensioners of the Company of Stationers, as well as two pieces of plate valued at $£ 20$, and a sum of $£ 5$ for a dinner to the Livery on the day of his burail. To Bonham Norton and Robert Barker he left $\mathrm{£5}$ apiece, and to his wife Jane Bill an annuity of $€ 300$ to be paid out of the profits of his share in the King's Printing House, and all those his parts of the houses in Blackfriars and St. Andrew's in the Wardrobe. He left three sons, John, Charles, and Henry, the first of whom succeeded to his father's share in the King's Printing House. John Bill nominated as his executors the Rev. John Mountford, William Austin, and Martin Lucas, gent. [Plomer, Wills, pp. 51-54]. Véase R.B. Mackerrow, ed., A Dictionary of Printers and Book sellers in England, Scotland and Ireland, and of Foreign Printers of English Books 1557-1640, ed. cit., pp. 31-33. Cfr. H.R. Plomer, Abstracts from the Wills of English Printers and Stationers, from 1492 to 1630, The Bibliographical Society, 1903. 
the Kress Library, Harvard Graduate School of Business Administration (Estados Unidos); the Central Reference Library (Bristol); y la Massachusetts Historical Society (Estados Unidos). La portada dice así:

$$
\text { MERCHANTS }
$$

AVIZO.

VERY NECESSARY FOR

their Sonnes and Seruants, when they

first send them beyond the Sea, as to

Spaine and Portingale, or other

Countries.

Made by their hearty wellwiller in Christ,

$$
\text { I. B. Merchant. }
$$

Eccles. I. Chap. II. verse. The feare of the Lord is glory, and gladnesse, and reioycing, and a ioyfull crowne, \& $c$.

LONDON, Printed by JOHN BILL. 1616.

El emblema del impresor es un mercurio alado, en posición vertical, con un pie apoyado en un globo ${ }^{56}$ :

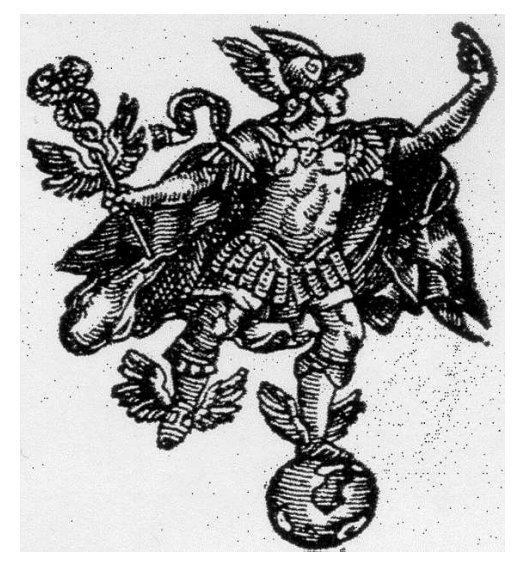

En esencia, esta edición es la misma que la de 1607, aunque tiene numerosas modificaciones ortográficas. El impresor utilizó marcas de mercaderes distintas a las de ediciones anteriores.

56 Ronald B. Mackerrow, Printers' \& Publishers' Devices in England and Scotland, 1485-1640, ed. cit., p. 352, e ilustración 382. 


\section{Edición de 1640}

Los derechos del libro se otorgaron a Mistress Joyce Norton ${ }^{57}$ y a Master Whitaker, de acuerdo con la escritura ejecutada por los albaceas de John Bill. Así, la última edición la imprimió Richard Whitaker ${ }^{58}$ en 1640. Poseemos prueba documental de la existencia de ejemplares en las siguientes bibliotecas: British Museum (Londres); the Bodleian Library (Oxford); the National Library of Scotland (Edimburgo); Queen's College (Oxford); the Folger Shakespeare Library (Washington); New York Public Library; y Columbia University Library (Estados Unidos). La portada reza así:

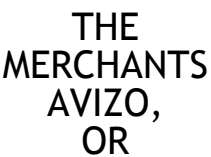

Instructions very necessary for their Sonnes and Servants, when

they first send them beyond the Sea, as to Spaine, and Portingale, or other

Countries.

Written by a wel-willer to youth, I. B. Merchant in Bristoll. London,

Printed by E.G. for Richard Whitaker and are to be sold at this shop at the signe of the Kings Armes in Saint Pauls Churchyard, 1640.

El emblema del impresor se compone de tres plumas.

Esta edición, sustancialmente, es la misma que las de 1607 y $1616 \mathrm{y}$, al igual que ellas, consta de los preliminares habituales, seguidos de setenta páginas numeradas. Una vez más hay modificaciones numerosas en la ortografía y en las marcas de los mercaderes.

57 NORTON (Joyce), (?) printer in London, 1632-7; The King's Arms, St. Paul's Churchyard. John Norton who died in 1612 left a widow Joyce, but it is not clear whether she is to be identified with the subject of this note. Joyce Norton was in partnership during the above period with Richard Whitaker. Véase R.B. MacKerrow, ed., A Dictionary of Printers and Booksellers in England, Scotland and Ireland, and of Foreign Printers of English Books 1557-1640, ed. cit., p. 205.

58 Véase Henry R. Plomer, A Dictionary of the Booksellers and Printers Who Were at Work in England, Scotland and Ireland from 1641 to 1667, The Bibliographical Society, London, 1907. En la entrada correspondiente a este editor, se recoge la siguiente información: WHITAKER (Richard), bookseller in London; King's Arms in St. Paul's Churchyard, 1619-48. Took up his freedom May 3rd, 1619. [Arber, iii, 685]. In partnership with Thomas Whitaker (...). They had an extensive business, and published much of the best literature of the period. Richard Whitaker was a warden of the Company of Stationers in the years $1643-5$. He died on February $5^{\text {th }}, 164_{8}^{7}$ (p. 192). 
Como hemos señalado, en todas las ediciones la ortografía varía de forma considerable, y ninguna de las empleadas se utiliza sistemáticamente. También hay diferencias en los caracteres, ornamentación y diversas marcas de mercaderes usados. Existen algunas alteraciones menores en las fechas de las cuentas, aunque puede que sea debido a errores de imprenta. Por lo general, estas diferencias no son significativas, exceptuando la eliminación del nombre de John Browne, que tan solo aparece en las tres primeras ediciones.

Excluyendo la primera edición, el resto están impresas en papel del mismo tamaño y poseen idéntico número de páginas. El contenido y la distribución de cada página prácticamente se corresponden, palabra por palabra, en todas ellas, salvo en discordancias menores, que se deben al uso de caracteres diferentes. Ninguna de ellas es, en ningún aspecto, una ampliación de la anterior.

No nos consta que The Marchants Avizo se reeditara después de 1640 . Es posible que la última edición no lograra alcanzar el éxito esperado, pues la obra ya tenía cincuenta años y nunca se había actualizado.

\section{VII}

El objetivo primordial de The Marchants Avizo no era ofrecer una perspectiva panorámica de la organización del mercado isabelino; ni tampoco era describir detalladamente los procesos económicos y las técnicas comerciales al uso cuando un mercader de Bristol enviaba mercancías a la Península Ibérica y a cambio recibía importaciones diversas de España y Portugal. No obstante, nos facilita cierta información de cómo funcionaba el comercio. Las cartas, cuentas y otros documentos comerciales puede, o puede que no constituyan una relación de los acontecimientos que realmente sucedieron; pero a partir de los mismos es posible reconstruir un relato, más o menos coherente, de los pasos que había que dar en una empresa comercial de esta naturaleza.

Para esta expedición concreta, Thomas Aldworth había puesto en el Joseph un cargamento de paños, cera y plomo. Además, tenía otras mercancías en el Gabriel, que, posiblemente, era su propio barco, y que había asegurado con dos mercaderes de Londres y un tercero de Bristol. Tenía que pagar una prima de un siete por ciento, pero, ante los muchos peligros en los que podía verse, estimó que merecía la pena hacerlo, a pesar de que muchos de sus contemporáneos no eran tan precavidos y 
preferían arriesgarse. Otra parte de la mercancía estaba en el Unicorn. Se sobreentiende que, para esta ocasión, también iban a zarpar otros barcos al mismo tiempo, con el fin de protegerse mutuamente. El Gabriel, el Minion y el Joseph llegaron juntos a Lisboa; en la expedición también participaba el Pleasure. La práctica de distribuir la mercancía entre varios barcos que navegaban en la misma dirección era algo habitual para los mercaderes.

Cuando la flota estuvo lista, Robert Aldworth se embarcó en el Joseph, llevando consigo, sin lugar a dudas, una copia de la "General Remembrance", así como las instrucciones para este viaje, en forma de "Particular Remembrance" ${ }^{\text {"59 }}$. Gracias a ésta sabía de qué mercancía era responsable, cuánto le había costado a su patrón, y el precio mínimo al que podía venderla. También se le dice qué tiene que comprar en España y Portugal, además de otras instrucciones. Está claro que actuaba en calidad de factor para, al menos, otro mercader, además de su patrón:

\section{A briefe order for making a marchants particular remembrance}

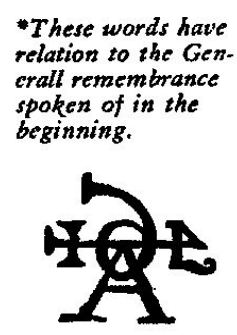

Remembrance for you my seruant R.A. that principally you do A with diligèce * read \& regard the counsel of that litle booke which I now geue you. And now (God willing) at your coming to Lisbon, you shal receaue out of the Ioseph wherin you go, one pack of ro. fine brode Clothes, and I. fine stamell cloth, with a gray cotten wraper, the which are marked as in the margent. The brode clothes stand me with all charges twelue pounds a cloth, and I hope they will yeld you in Lisbon about 52. duckets. The Stämel standeth me in 17 . pound, and I hope will yeeld you 75 . Duckets : \& the wrapper cost 3o. shillings. All which doe you your best indeuoure, to sell as the time serueth. More (God willing) you shall receiue 3 . Hogshead of waxe, marked also with the former marke, wherein is 14 . hundred and 13 . pound. It doth stand me all charges about 5. pound 12. shillings the hundreth: the which you may sell for 25. Duckets a Kintal, if the time so offereth. More also you shall receaue for my acompt 20 tunnes of lead, conteining 345. peeces marked as in the top of the former page: the which if you cannot sel to some reckning in Lisbon, do you let it goe along in the Ship to S. Lucar, and there to sell it as well as you may: I hope it will be worth 22. Rials the Kintall.

59 Cfr. "A briefe order for making a marchant particular remembrance", The Marchants Avizo, 1589, fol. 50. 
Salió de Kingroad el día estipulado. Su primera carta, acerca de los vientos desfavorables que obligaron a su barco a detenerse en Hilford y del hecho de que llegó a Lisboa dieciséis días después de su salida, sirve para recordarnos las dificultades de las comunicaciones marítimas de entonces. Incluso cuando llegó a Portugal sufrió un retraso en el cumplimiento de sus obligaciones. Alude, sin ningún tipo de comentario, a que no había desembarcado la mercancía ni vendido nada, "for it is but 3 . dayes since we arriued"60.

Entre tanto, no había perdido el tiempo. Había concertado su alojamiento y puesto en contacto con otros mercaderes, incluido "W.O.", amigo de su patrón, al que se menciona en las instrucciones. Se las arregló para avisar a Thomas Aldworth de los precios que se pagaban en el mercado por varias clases de paño, plomo y trigo; y para informarle de ciertas mercancías portuguesas que podían interesar a su patrón: pimienta, clavo, macia, nuez moscada, canela, calicó, jabón, sal y palo. Diez o doce días más tarde volvió a escribir dándole detalles del precio al que había vendido parte de los paños, cera y plomo. Los paños los compró Jacques Magomes, y la cera Bernard Priget. Para vender algunos paños se vio obligado a hacer descuentos. Sus "implements" o compras fueron: pimienta, que se la suministró Michael Sebra; clavo, macia y canela, que se los compró a Lewis Betron y Martin Ferbuc.

En Lisboa, el muchacho también actuó de agente para otro mercader inglés, para el que vendió paños finos (popelin) y al que envió pimienta y clavo en el Minion. Otro servicio que realizó para este mercader consistió en cobrar una deuda y enviar el dinero, por letra de cambio, a Sevilla. No se especifica si recibía algún tipo de compensación por estas tareas. Existían agentes a comisión y factores que se encargaban de estas funciones, aunque no cabe duda de que los mercaderes ingleses, con negocios en la Península, estaban dispuestos a hacerse favores. El 7 de noviembre, el joven anuncia su intención de trasladarse a Sanlúcar de Barrameda. Era corriente, en aquellos que se dedicaban al comercio con la Península, ir primero a Portugal y después a España. Según parece, llegó a Sanlúcar en diciembre. Allí vendió los paños y el plomo que le quedaban y mandó a Inglaterra aceite, cochinilla y jerez. Cada envío llevaba la correspondiente marca del mercader y un conocimiento de embarque,

60 "A letter to be written to your Master presently upon arriual at your Port", The Marchants Avizo, 1589, fol. 9. 
debidamente firmado por el sobrecargo del barco. Para gestionar todos estos negocios, es casi seguro que Robert Aldworth consultó a "I.T.", amigo de su patrón en Sanlúcar, al que también entregaría el regalo que Thomas Aldworth le enviaba desde Inglaterra.

En Sanlúcar el joven factor necesitó dinero para terminar con todas las operaciones que su patrón le había encomendado, incluida la reserva para el transporte de quince toneladas en el Unicorn, del que Thomas Aldworth ya era usuario. Esta contingencia se contempla en la "Particular Remembrance", por lo que se dirigió a "T.M.", que le prestó 100 ducados. Acordaron que se los devolvería, aplicando una tasa por ducado; con tal fin, extendieron una letra de cambio pagadera, en el plazo de quince días, a partir de la llegada del Gabriel a su puerto de descarga en Inglaterra ${ }^{61}$ :

But if it fall out that you shall want any monies to furnish the lading of 15 . tunnes in the Vnicorne, which I am bounde vnto: thē request so much friēdship of T.M. to furnish that which you want in monyes by exchang: and agree with him for the exchange so good cheape as you can, as about 6 . shillings and 4 . pens or 6 . shillings and 8. pens the Ducket, and this my letter shall be your warrant.

Robert Aldworth no permaneció siempre en Sanlúcar durante su estancia en España. El día 25 de enero escribe desde Sevilla a un amigo en Portugal, rogándole que entregue la carta que le envía a un mercader de paños de Lisboa y que se haga cargo de los 100 ducados que, por escrito, le había exigido que le pagara. Todo parece indicar que el joven debió recibir otras instrucciones, después de abandonar Portugal, pues su amigo recibió la sugerencia de invertir el dinero en pimienta. Quizá Thomas Aldworth se había percatado de que su pimienta estaba alcanzando un buen precio en el mercado y deseaba recibir más envíos.

Mientras permaneció en Sevilla, Robert Aldworth escribió a otro amigo pidiéndole que recibiera un cargamento de plomo del Gabriel, cuando éste llegara a Sanlúcar, que lo vendiera y, con lo recaudado, fuera a Jerez a comprar ocho barriles del mejor vino y lo enviara a Inglaterra. El dinero sobrante se lo debía mandar, inmediatamente, a Sevilla.

61 Cfr. "A briefe order for making a marchant particular remembrance", The Marchants Avizo, 1589, fols. 50-51. 
El objeto de su visita a la ciudad hispalense se deduce por las cuentas, pues Francisco Bera, que le había comprado plomo, y Sebastián de Laga, que le había vendido aceite, eran sevillanos. Pedris Meris, mercader de paños, era de Sanlúcar. El vino lo había adquirido de Martín de Leso, ciudadano de Jerez.

Las cuentas, que se recogen en The Marchants Avizo, nos suministran algunos datos sobre la verdadera naturaleza del comercio de aquel entonces. Así, se detallan las tasas que había que abonar para enviar mercancía desde los puertos españoles y portugueses; en ellas se relaciona una amplia gama de impuestos de aduana e incorporan referencias a determinadas prácticas como la envoltura doble para la pimienta, el lavado de las cubas utilizadas para transportar aceite, el ajuste de los toneles antes y después de ponerlos a bordo, y la venta de las fundas que se colocaban en los fardos de paños para su protección durante la travesía ${ }^{62}$ :

The 3. Day of Ianuarie 1589

Oyles ro. pipes for the account of my master Alderman Aldworth, oweth Ir5.V.600 Meruedis for 400 . Roues of Oyle, which cost the first penny 8. Rials and a halfe the Roue. Amount. o (More oweth these charges following)

For 10. leare pipes for the Oyles, which cost 24. Rio. and a halfe the Pipe. Amount into Spanish Meruedis. 0 .

For watring the Pipes, and carriage of them at 15. Mer. the Pipe. o.

For Marco almeran: and bota fuera, at 25. Mer, the pipe. ....

For $S$. Georges custome at one Riall per Tunne. 0 . Pipe....

For yeffo [sic] for the Pipes at ro. Mer. the Pipe. o

For carriage of them to the Shrof. [sic] at 2x. Mer. the Pipe. ............................................................... the

Eor filling, rowling and hooping of them, at 45 . Mer. the Pipe. 0 .

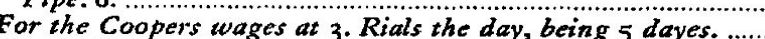

For Nailes, Corke, Canuas, and Leather.

For Incomiendo

at one par 100. 0

For brokerage at halfe per yod 0

For cartage at 5. Rials the Tunne.

For barkage at 7. Rials 12. Mer. the Tunne.

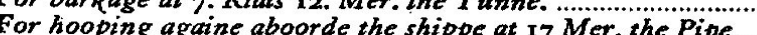

For hundage at one Riall per Tunne

For cuindage at r

For windage at r7. Mer. the Tunne .............

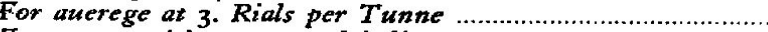

For my prowision at 2. and halfe per roo. o

Summe Totall

Mer
$000 M .115 . V .600$

8.V.330

$V .150$

.250

V.170

$V . x 00$

$V .210$

$\{$ Summe Totall $\quad$ oooM.r33.V.976

Note that the customes and dueties vpon wares in Spaine azs Portingale doe oftentimes change: therefore you must ewery voyage, make diligent inquiric of it, and so accordingly charge the account.

62 The Marchants Avizo, 1589, fols. 41-42. 


\begin{tabular}{l} 
Marchants Aviso \\
The 3. day of Ianuarie 1589. \\
Per contra: is due r33.V.976. Meruedis: in the whole \\
charges of 5. Tunnes of Oyles containing 400. Roues: laden \\
aboord the Gabriel in S. Lucar in Andolosia under this \\
marke in the margent: and bought of Sebastian de Lega, \\
Gentleman of Cyuell. Amount. \\
\hline Summe totall.
\end{tabular}

El valor de The Marchants Avizo no solo reside en los datos que facilita sobre las técnicas comerciales, sino también en el hecho de que, en su conjunto, nos presenta un relato, narrado desde dentro, de los problemas que un mercader debía afrontar a diario en sus negocios. Refleja algunas realidades del comercio entre Inglaterra y la Península; así vemos al mercader isabelino preocupado, no por los grandes asuntos de la política del comercio internacional, sino por las pequeñas cosas, aunque no por ello menos importantes, de si los agentes pueden escribir cartas apropiadas o distinguir el buen añil del malo; y en esto consisten los elementos correctores de la tendencia a considerar el comercio internacional sólo en términos de fuerzas económicas ciegas. Una narración detallada como ésta, basada en la experiencia personal, añade una nota de realismo a las generalizaciones sobre la naturaleza y alcance del comercio isabelino. Y es más importante, si cabe, por su singularidad.

Con independencia de lo que dice sobre detalles procedimentales y técnicas de comercio, The Marchants Avizo es interesante por lo que nos dice de la actitud del mercader ante su profesión. No es necesario aceptar que John Browne es una figura típica de su clase social, pero sus opiniones son valiosas, pues muy pocos de su gremio expresaron sus ideas por escrito.

Una de las características de The Marchants Avizo es la forma que tiene de mezclar los consejos sobre asuntos comerciales con la enseñanza moral y religiosa. Sobre este aspecto, podemos decir que el escritor es un continuador, en contra de un sentido religioso bastante diferente, de la tradición medieval de que la economía no debe estar separada de la ética. Louis $B$. Wright ${ }^{63}$ ha señalado que el libro, y en

63 Louis B. Wright, Middle-Class Culture in Elizabethan England, The University of North Carolina Press, Chapel Hill, 1935, pp. 161-2, passim. 
concreto las máximas del final, "epitomize the bourgeois philosophy that virtue pays in things of this world" $y$ que "With such good advice, the business was prepared to prosper in both this world and the next". Sin duda hay diversidad de opiniones al respecto, pero también se puede argumentar que el autor no parece estar obsesionado con la enseñanza de una moralidad apropiada para aquellos que desean tener lo mejor de ambos mundos; que no considera la religión a la luz de las ventajas que puede o no producir, aunque no tiene inconveniente en señalar que una conducta apropiada hace del aprendiz un mercader y un hombre mejor.

Durante algún tiempo, en las décadas pasadas, se mantuvo viva una controversia que centraba su atención en el surgimiento de la burguesía en la Inglaterra del siglo XVI. Durante el reinado de Isabel I (1558-1603), los mercaderes todavía no habían alcanzado la prominencia social a la que llegarían más tarde, pero su importancia iba en aumento. El poema introductorio de The Marchants Avizo muestra que el autor consideraba al mercader como la piedra angular de toda la economía, y que el objetivo principal de la obra era contribuir a la formación de los jóvenes para que fueran miembros dignos de una gran profesión ${ }^{64}$ :

When marchants trade proceedes in peace.

And labour prosper well:

Then common weales in wealth increase, As now good proofe can tell

For when the marchants trade was free, His ventures for to make:

Then euery art in his degree

Some gaines thereof did take

Es interesante observar en The Marchants Avizo la ausencia absoluta del espíritu agresivo y nacionalista que siempre se ha atribuido a la Inglaterra isabelina, lo que, en cierto modo, nos indica la actitud personal del autor, que es posible compartieran muchos mercaderes. La guerra con España fue saludada por la corte, el soldado en busca de fortuna, los lobos del mar y el protestante acérrimo; pero para el mercader significó, con excesiva frecuencia, una crisis de su negocio. Resulta sorprendente encontrar un escritor que inste a sus compatriotas a ser humildes y corteses en su trato con los españoles, precisamente un año después de la derrota de la Armada Invencible.

64 The Marchants Avizo, 1589, "To the Reader". 
Los profesores R.S. Lopez e I.W. Raymond, en relación con los mercaderes medievales, han señalado que

\begin{abstract}
Men who in their own transactions showed the greatest daring and inventiveness became circumspect and orthodox in giving advice to others. They tuned down their passions, their virtues, and their skills to an ideal of golden mediocrity ${ }^{65}$.
\end{abstract}

En cierta medida, también sucede con el mercader isabelino, en el caso de que consideremos a John Browne como prototipo de aquél. El tono comedido de su obra no refleja, en absoluto, el espíritu aventurero de la Inglaterra isabelina. No hay ni rastro del entusiasmo, peligros y preocupaciones inherentes a la arriesgada empresa del comercio exterior, donde la fortuna sólo se lograba con esfuerzo y se perdía con facilidad, y el desastre podía caer sobre el mercader por causas ajenas a sus actividades. Quizá John Browne prefería la tranquilidad de practicar las virtudes que proclamaba, en lugar de preocuparse excesivamente por los riesgos de su profesión. Puede que estimara más apropiado enseñar a sus discípulos las normas convencionales del juego y dejar que fuesen ellos mismos los que indagaran, por experiencia propia, en las posibilidades de jugar utilizando otras formas menos ortodoxas.

VIII

En su Colección de documentos, Medieval Trade in the Meditarrean World ${ }^{66}$, R.S. Lopez e I.W. Raymond presentan una relación de manuales, métodos contables, correspondencia comercial, tratados de ética y escritos medievales en general, sobre técnicas comerciales y prácticas empresariales. No sólo existieron tratados de aritmética, contabilidad y rutas comerciales, sino también manuales sobre práctica comercial en su acepción más amplia:

These manuals cover nearly every subject of interest to a merchant -descriptions of wares, measures, moneys, tariffs, itineraries, and sometimes complete portolani;

65 Robert S. Lopez and Irving W. Raymond, Medieval Trade in the Mediterranean World, Oxford University Press, 1955, p. 408.

66 Ibid. 
arithmetic formulae to calculate compound interest, perpetual calendars; methods to make alloys and to test chemicals; economic theories; and advice on how to dodge custums inspection ${ }^{67}$.

La mayor parte de lo que John Browne hace con ciertos aspectos del comercio inglés del siglo XVI, ya se había hecho anteriormente en contextos diferentes, aunque ni él ni ninguno de sus contemporáneos conocían este extremo. John Browne se hubiera sorprendido, y se habría sentido honrado, si hubiera sabido que entre los precursores de The Marchants Avizo tenemos obras como The Book of Knowledge of the Beauties of Commerce and of Cognizance of Good and Bad Merchandise and Falsifications ${ }^{68}$, escrito en Damasco, probablemente en el siglo IX, por Abdu al-Fadl Ja'far ibn 'Ali al-Dimishqui, y La Pratica della mercatura, de Francesco di Balduccio Pegolotti, escrito en Florencia a principios del siglo XIV ${ }^{69}$. El manuscrito se conserva en la Biblioteca Riccardiana de la mencionada ciudad italiana, con el número 2441; es un volumen en cuarto grande, encuadernado en cuero labrado y escrito en papel de algodón de buena calidad. El único ejemplar existente lo terminó en Florencia, el 9 de Marzo de 1472, Filippo di Niccolaio Frescobaldi, que lo transcribió, a su vez, de una copia del libro de Agnolo di Lotto dall'Antella, que lo había copiado del original de Francesco Balducci.

El desarrollo de una literatura en inglés sobre la formación del hombre de negocios fue tardía. En nuestra introducción a la edición facsímil y traducción española de An Essay on the Proper Method of Forming a Man of Business: $1716^{70}$, señalamos algunos de los primeros tratados ingleses de aritmética, teneduría de libros, derecho mercantil y ética empresarial que, creemos, estaban pensados para la educación de los futuros mercaderes. El número de estas obras fue creciendo en la segunda mitad del siglo XVI, si bien The Marchants Avizo parece ser el primer libro de texto de información general de esta índole que se publicó en Inglaterra. Louis B. Wright lo describe como "one of the best of

\footnotetext{
67 Ibid., p. 342.

68 Véase la traducción alemana de H. Ritter, "Ein arabisches Handbuch der Handelswissenschaft", Der Islam, VII (1917), pp. 17-26.

69 Véase Francesco Balducci Pegolotti, La Pratica della mercatura, ed. by Allan Evans, The Mediaeval Academy of America, Cambridge, Mass., 1936, pp. 293-97.

70 Thomas Watts, Ensayo sobre el método más idóneo para la formación del hombre de negocios. 1716, Introducción: J.J. Lanero, Traducción: J.C. Santoyo y S. Villoria, Universidad de León, 1994.
} 
these mercantile manuals of general information", y añade que "no succeeding handbook managed to crowd so much useful and moral information into as brief a compass as John Browne's Avizo ${ }^{71}$.

Tan solo existe otra pieza isabelina de carácter económico que pueda ser comparable con The Marchants Avizo. Se trata de un manuscrito, de seis páginas de extensión, que se conserva con los State Papers, Domestic, Elizabeth (vol. 255, no. 56), en Her Majesty's Public Record Office. Se le menciona brevemente en el Calendar of State Papers, Domestic Series, of the Reign of Elizabeth, 1595- $7^{72}$ :

56. "A special direction for divers trades of merchandize to be used for sundry places, upon advertisements, as well for the chusing of the times and wares for every of those places." The principal exports are cloths, Manchester cottons, hides, leather, wheat, \& c., salt, fish, ordnance, butter and cheese, whale oils, cutlery, alum, wines, and silks. The imports, oranges and lemons, timber, pitch and rosin, wines, flax and hemp, furs, cordage, linen, silks, currants, sugars, saltpetre, dates, molasses, sweet oils, spices, large onions, woad, wax, pitch, cross-bows and sword blades, prunes, tar, gold, silver, pearls, hides, salt beef, \& c. The places traded with are Galicia, St. Jean de Luz, Nerva, Rye, and Revel, the islands of Scotland, Rouen, Morlaix, and St. Malo, the Levant, Barbary, Andulusia, Lisbon, St. Michael, and Tercera, the Canaries, St. Nicholas, Russia, Bilboa, Bourdeaux, Rochelle, West Indies, Brazil, Ireland, \& c. With remarks about the times of sending out vessels to the several places and lists of prices of goods sent to or brought from Spain. [6 pages].

El manuscrito no tiene fecha y es anónimo. Su encabezamiento completo es el siguiente:

A speciall direction for divers trades of merchaundize to be used for soundrie placis upon adverticementes, as well for the chusinge of the time and wares for every of those placis. Most Beneficiall for those that use the trade of marchandize.

71 Louis B. Wright, Middle-Class Culture in Elizabethan England, The University of North Carolina Press, Chapel Hill, 1935, pp. 60; 162.

72 Calendar of State Papers, Domestic Series, of the Reign of Elizabeth, 15951597, Preserved in Her Majesty's Public Record Office, ed. by Mary Anne Everett Green, Longmans, Green, Reader, and Dyer, London, 1869, p. 152. 
A diferencia de The Marchants Avizo, alude a una variedad inmensa de mercados en los que los ingleses tenían negocios, si bien España, Portugal y sus dominios reciben una atención especial, mientras que los mercados alemán y flamenco se tocan solo por encima. Al igual que el autor de The Marchants Avizo, el escritor anónimo se preocupa de dar consejos prácticos para hacer negocios y qué comportamiento hay que observar. Informa con detalle de los distintos productos que se pueden encontrar en cada una de las regiones de que se ocupa, y de las mercancías que serían más beneficiosas para la exportación:

\begin{tabular}{|c|c|}
\hline $\begin{array}{l}\text { the } \\
\text { are with } \\
\text { eate }\end{array}$ & $\begin{array}{l}\text { Item, for all the parts of Galicia, course cloth and } \\
\text { Bridgwaters, northeren halfe clothes, manchester cottons, } \\
\text { hides, cal[f]skines, shepe skines, dressed brecknockes, } \\
\text { bristowe frises, and tymbye fryses, wexe, flaninge and } \\
\text { wedmoles of Wales, wheate, Butter, chease, highe } \\
\text { cotton fryses of carmarthen in Sowthe Wales. }\end{array}$ \\
\hline $\begin{array}{l}\text { mmodi- } \\
\text { s re- } \\
\text { ned } \\
\text { m } \\
\text { ence. }\end{array}$ & $\begin{array}{l}\text { Item, the comodities thence ar wynes of Rubad } \\
\text { and Orenges and Lemons and Tymber and Boorde } \\
\text { chestnuttes and walnutes, where of the[re] is gr } \\
\text { store and goode cheape, especially in villia viziosa. } \\
\text { you must take hede that you gree with the custor } \\
\text { for your custome before you land your wares, for } \\
\text { will gree with you for two in the hondert. Other w } \\
\text { they will make you paye viii or } x \text { in the hondert. }\end{array}$ \\
\hline
\end{tabular}

En la información que facilita incluye una lista de precios de los productos a los que hace mención: "The prices of all the spannishe wares comonlie used to be laden", "The prises of all the englishe wares comonlie to be laden owte of england"74, y la mejor época del año para hacer negocios en los distintos mercados: "All the yeare accordinge to yowr adverticementes", "At mighelmas and Easter becaus of the martes"

73 R.H. Tawney and Eileen Power, eds., Tudor Economic Documents, 3 vols., Longmans, Green and Co., London, 1924, vol. III, p. 200.

74 Ibid., pp. 208-9.

75 Ibid., pp. 202-3. 
Su obra está repleta de indicaciones sobre impuestos de aduana, salvoconductos, y otros datos necesarios para un mercader. A Speciall Direction está llena de reminiscencias de The Marchants Avizo, o a la inversa, en su insistencia en lo importante que es que el mercader disponga de una información precisa de la situación del mercado:

\begin{abstract}
The hole trade of the marchaunte standith upon diligent adverticements.

Item, take this for a gennerall Rule in all kinde of merchaundize, that yt is not Sufficient for you to knowe all this, unles you Allwayes doe procuer to have adverticementes owt of all placis; otherwyse you may be prevented by other men ether before or After. And commonlye there can be nothinge well sold when you shalbe bounde to lade the same shipp backe againe within xxv or thirttie dayes. Therefore adverticement is good and the principall thinge that belongethe to $A$ Merchaunte $^{76}$.
\end{abstract}

Y de nuevo encontramos ecos de The Marchants Avizo en el siguiente párrafo:

And because that wieght and mesure doth differ in many realmes and in manye places of one realme, the first thinge that a marchante or factor dowth, after his cominge to any towne of trade, to informe himesealfe of their weights and mesures, and so like wise of the cowstomes and all other dewties, or wether the same is to be charged upon the byer or the seller, as well outwards as inwards ${ }^{77}$.

A Speciall Direction ha sobrevivido en un manuscrito, copiado por un escribano, sin ninguna indicación de quién fue su autor. Es indudable que se escribió durante el reinado de Isabel I. Las alusiones a "her Majesty" y los caracteres de la escritura lo sitúan en los reinados de María Tudor o Isabel I; si bien la referencia a los españoles como "olde Ennemyes", excluye la posibilidad del reinado de la primera. La importancia que se concede al comercio con España nos induce a fecharlo antes de 1585, pues a partir de ese año, las transacciones entre España e Inglaterra

76 Ibid., pp. 207-8.

77 Ibid., pp. 209-10. 
quedaron prácticamente canceladas para el resto del reinado de Isabel I. Por otro lado, la mención que se hace a las "restrains" sobre el comercio con España, nos incita a fijar la fecha en el reinado durante el que tales restricciones eran habituales. Por consiguiente, es posible que el manuscrito pertenezca a la década 1575-1585.

Se desconoce quién fue el autor; es probable que fuera un mercader de amplia experiencia. Además, resulta evidente que escribió el documento para el estudio detenido y minucioso de algún Consejero influyente del Privy Council (Consejo Privado de la Soberana), al que le da el tratamiento de "your honor" (señoría), y al que aconseja que pase alguna de las instrucciones que le da a los agentes de aduanas.

El Profesor Conyers Read, que fue el primero en dar el manuscrito a la imprenta ${ }^{78}$, sostiene que la licencia para "A direction for trades of marchandize" la pudo dar Sir Francis Walsingham, Primer Secretario de la reina Isabel I, cuyo interés por el comercio es bien conocido ${ }^{79}$. Es incluso posible que el documento se escribiera para él. En cualquier caso, sugerimos la idea de que existe una relación entre The Marchants Avizo y A Speciall Direction. Quizá John Browne fue el responsable de ambos; o es probable que el punto de unión haya que buscarlo en Thomas Aldworth, del que sabemos que durante los años 1582 y 1583 se carteó con Walsingham a causa de la propuesta de una expedición que a éste le había formulado Sir Humphrey Gilbert ${ }^{80}$. Finalmente, el tratamiento de "your honor"

78 Conyers Read, "English Foreign Trade under Elizabeth", The English Historical Review, XXIX (1914), pp. 515-524. Posteriormente lo publicó Norman Scott Brien Gras, "A Speciall Direction for Divers Trades", en The Evolution of the English Corn Market. From the Twelfth to the Eighteenth Century, Harvard University Press, Cambridge, Mass., 1915, pp. 429-439; y R.H. Tawney and Eileen Power, Tudor Economic Documents, ed. cit., pp. 199-210.

79 Véase Conyers Read, Mr Secretary Walsingham and the Policy of Queen Elizabeth, 3 vols., The Clarendon Press, Oxford, 1925.

80 David Beers Quinn, The Voyages and Colonising Enterprises of Sir Humphry Gilbert, 2 vols., The Hakluyt Society, London, 1940. Reproducimos una de las cartas que se intercambiaron Walsingham y Thomas Aldworth (vol. II, p. 347):

A letter of Sir Francis Walsingham to Master Thomas Aldworth, merchant, and at that time Maior of the Citie of Bristoll, concerning their adventure in the Westerne discouerie.

After my heartie commendations, I have for certaine causes deferred the answere of your letter of November last till now, which I hope commeth all in good time. Your good inclination to the Westerne discoverie I cannot but much commend. And for that Sir Humfrey Gilbert, as you have heard long since, hath bene preparing into those parts being readie to imbarke within these 10. dayes, who needeth some further supply of shipping then yet he hath, I am of opinion that you shall do well if the ship or 2. barkes you write of, be put in a readinesse to goe alongst with him, or so some after you may. I hope this travel will proove profitable to the Adventurers and generally beneficiall to the whole realme: herein I pray you conferre with these bearers, M. Richard Hackluyt, 
excluye a Sir William Cecil, también Secretario de la reina, a no ser que el manuscrito fuera anterior a 1571, año en el que cesa en su cargo al concedérsele el título de Lord Burghley, lo que es improbable.

\section{IX}

Si la información que contiene $A$ Speciall Direction se hubiera compaginado con la de The Marchants Avizo, el lector isabelino habría dispuesto de un manual de comercio exterior mucho más completo. A Speciall Direcion no se publicó; pero en una época en la que constantemente se editaban "Handbooks for Improvement" y "Guides to Godliness", para satisfacer la demanda de los diferentes sectores de la sociedad, los mercaderes isabelinos debieron agradecer que John Browne sacara a la luz un manual de primer orden en el que se combinan dos objetivos: enseñar a los jóvenes técnicas comerciales y deontología empresarial. La opinión favorable que les mereció la demostraron con tres ediciones en tres años consecutivos; este interés se mantuvo vivo durante las primeras décadas del siglo XVII, pues no se publicó nada tan detallado hasta que, en 1638, Lewes Roberts dio a la imprenta The Merchants Mappe Of Commerce ${ }^{81}$; si bien éste era un volumen en folio, de varios cientos de páginas y muy distinto de la pequeña guía de bolsillo de John Browne. Después de todo, siempre se cumplirá la máxima que R.W. Emerson escribió, en el siglo XIX, en su libro The Conduct of Life: "The craft of the merchant is this: bringing a thing from where it abounds, to where it is costly" (El arte del mercader consiste en llevar un producto del lugar donde abunda a donde se paga caro).

and M. Thomas Steventon, to whome I referre you: And so bid you heartily farewell. Richmond the II. of March. 1582.

Your loving Friend,

Francis Walsingham.

81 The Merchants Mappe Of Commerce: Wherein, The Vniversall Manner and Matter of Trade, is compendiously handled. The Standerd and currant Coines of sundry Princes, observed. The Reall and Imaginary Coines of Accompts, and Exhanges, expressed. The Naturall and Artificiall Commodities of all Countries for transportation declared. The Weights and Measures of all eminent Cities and Townes of Traffique, collected and reduced one into another; and all to the Meridian of Commerce practised in the famous Citie of London. By Lewes Roberts, Merchant. Necessary for all such as shall be imployed in the publique Affaires of Princes in forreigne Parts; for all Gentlemen and others that travell abroad for delight or pleasure, and for all Merchants of their Factors that exercice the Art of Merchandizing in any part of the habitable World. London. Printed by R. O[ulton] for R. Mabb, 1638. 
BIBLIOGRAFÍA

Acts of the Privy Council.

Adam's Chronicle of Bristol. Bristol, 1910.

Aprenticeship Books. Bristol Record Office.

ARBER, E. (1875-1894) A Transcript of the Registers of the Company of Stationers of London, 1554-1640, 5 vols. London.

BARRETT, William (1789) The History and Antiquities of the City of Bristol. Bristol.

BEAVEN, A.B. (1899) Bristol Lists. Bristol.

BRAMBle, Lt. Colonel (1893) "A Rare Bristol Book", Proceedings of the Clifton Antiquarian Club, 1888-1893. Exeter.

BROWNE, John $(1589,1590,1591,1607,1616,1640)$ The Marchants Avizo. Very Necesarie for Their Sonnes and Seruants, When They First Send Them Beyond the Seas, As To Spaine and Portingale of Other Countreyes. Made by their hartie wellwiller in Christ. I.B. Marchant. London: Richard Field for William Norton.

Burgess Books. Bristol Record Office.

BURGON, John William (1836) The Life and Times of Sir Thomas Gresham; Compiled Chiefly from His Correspondence Preserved in Her Majesty's State-Papers Office: Including Notices of Many of His Contemporaries, 2 vols. London.

Calendar of State Papers, Domestic Series, of the Reign of Elizabeth, 15951597, Preserved in Her Majesty's Public Record Office, ed. by Mary Anne Everett Green. London: Longmans, Green, Reader, and Dyer, 1869.

CONNELL-SMITH, Gordon (1951) Forerunners of Drake: A Study of English Trade with Spain in the Early Tudor Period. London: Longmans, Green and Co.

DAY, Angel (1592) The English Secretorie, wherein is contayned a perfect method, for the inditing of all manner of epistles and familiar letters, together with their diuersities, enlarged by examples vnder their seuerall tytles.... London: Robert Walde-graue, 1586 / R. Jones for C. Burbie, 1592.

DE ROOVER, Raymond (1949) Gresham on Foreign Exhange: An Essay on Early English Mercantilism with the Text of Sir Thomas Gresham's Memorandum for the Understanding of the Exchange. Cambridge, Mass.: Harvard University Press. 
Dictionary of National Biography.

DufF, E. Gordon (1905) A Century of the English Book Trade: Short Notices of All Printers, Stationers, Book-Binders, and Others Connected with It from the Issue of the First Dated Book in 1457 to the Incorporation of the Company of Stationers in 1557. London: The Bibliographical Society.

GORDON, Cosmo (1937) Bibliography of Bookkeeping. London: The Institute of Chartered Accountants in England and Wales.

GRAS, Norman Scott Brien (1915) The Evolution of the English Corn Market: From the Twelfth to the Eighteenth Century. Cambridge, Mass.: Harvard University Press.

Great Orphan Books. Bristol Record Office.

LANero FERnÁNDEZ, J. y E. ORTEGa MONTES (2007) "De aprendiz a mercader: El factor en el comercio internacional inglés del siglo XVI", Pecvnia, 5, pp. 145-180.

LOPEZ, Robert S. and Irving W. RAYMOND (1955) Medieval Trade in the Mediterranean World. Oxford University Press.

MCGRATH, Patrick, ed. (1952) Records Relating to the Society of Merchants Venturers of the City of Bristol in the Seventeenth Century. Bristol Record Society.

MCKERROW, R.B., ed. (1910) A Dictionary of Printers and Booksellers in England, Scotland and Ireland, and of Foreign Printers of English Books 1557-1640. London: The Bibliographical Society.

McKerrow, R.B. (1913) Printers' \& Publishers' Devices in England and Scotland, 1485-1640. London: The Bibliographical Society.

The Mayor's Audits. Bristol.

MURRAY, David (1930) Chapters in the History of Bookkeeping, Accountancy and Commercial Arithmetic. Glasgow.

PegolotTI, Francesco Balducci (1936) La Pratica della mercatura. Ed. by Allan Evans. Cambridge, Mass.: The Medieval Academy of America.

PLOMER, H.R. Abstracts from the Wills of English Printers and Stationers, from 1492 to 1630. The Bibliographical Society, London, 1903.

Plomer, H.R. (1907) A Dictionary of the Booksellers and Printers Who Were at Work in England, Scotland and Ireland from 1641 to 1667. London: The Bibliographical Society.

Public Record Office. High Court of Admiralty. 
QUINN, David Beers (1940) The Voyages and Colonising Enterprises of Sir Humphrey Gilbert, 2 vols. London: The Hakluyt Society.

READ, Conyers (1914) "English Foreign Trade under Elizabeth", The English Historical Review, XXIX, pp. 515-524.

- (1925) Mr Secretary Walsingham and the Policy of Queen Elizabeth, 3 vols. Oxford: The Clarendon Press.

RITTER, H. (1917) "Ein arabisches Handbuch der Handelswissenschaft", Der Islam, VIII, pp. 17-26.

ROBERTS, Lewes (1638) The Merchants Mappe Of Commerce: Wherein, The Vniversall Manner and Matter of Trade, is compendiously handled. The Standerd and currant Coines of sundry Princes, observed. The Reall and Imaginary Coines of Accompts, and Exchanges, expressed. The Naturall and Artificiall Commodities of all Countries for transportation declared. The Weights and Measures of all eminent Cities and Townes of Traffique, collected and reduced one into another; and all to the Meridian of Commerce practised in the famous Citie of London. London: R. O[ulton] for R. Mabb.

ROBERTSON, Jean (1942) The Art of Letter Writing: An Essay on the Handbooks Published in England During the Sixteenth and Seventeenth Centuries. The University Press of Liverpool.

SALTER, F.R. (1925) Sir Thomas Gresham (1518-1579). London: Leonard Parsons.

Shillington, V.M. and H.B. Wallis Chapman (n.d.) The Commercial Relations of England and Portugal. London.

TAWNEY, R.H. and Eileen POWER (1924) Tudor Economic Documents Illustrating the Economic and Social History of Tudor England, 3 vols. London: Longmans, Green and Co.

WATTS, Thomas (1994) Ensayo sobre el método más idóneo para la formación del hombre de negocios. 1716. Introducción J.J. Lanero, Traducción: J.C. Santoyo y S. Villoria. Universidad de León.

WHEELER, Iohn (1601) A Treatise of Commerce. Wherein are shewed the commodities arising by a well ordered and ruled Trade, such as that of the Society of Merchants Adventurers is proued to be.... London: Iohn Harison.

WRIGHT, Louis B. (1935) Middle-Class Culture in Elizabethan England. Chapel Hill: The University of North Carolina Press. 